\title{
Sources of sediment-bound organic matter infiltrating spawning gravels during the incubation and emergence life stages of salmonids
}

\author{
A.L. Collins ${ }^{a, c, *}$, L.J. Williams ${ }^{a}$, Y.S. Zhang ${ }^{a}$, M. Marius ${ }^{b}$, J.A.J. Dungait ${ }^{a}$, D.J. Smallman ${ }^{b}$, \\ E.R. Dixon ${ }^{c}$, A. Stringfellow ${ }^{\text {b }}$, D.A. Sear ${ }^{\text {c }}$, J.I. Jones ${ }^{\text {d }}$, P.S. Naden ${ }^{\text {e }}$ \\ a Sustainable Soils and Grassland Systems Department, Rothamsted Research-North Wyke, Okehampton, Devon EX20 2SB, UK \\ ${ }^{\mathrm{b}}$ Civil Engineering and Environment, University of Southampton, Highfield, Southampton S017 1BJ, UK \\ ${ }^{\mathrm{c}}$ Geography and Environment, University of Southampton, Highfield, Southampton SO17 1BJ, UK \\ d School of Biological and Chemical Sciences, Queen Mary University of London, Mile End Road, London E1 4NS, UK \\ e CEH Wallingford, Maclean Building, Benson Lane, Crowmarsh Gifford, Wallingford, Oxfordshire OX10 8BB, UK
}

\section{A R T I C L E I N F O}

\section{Article history:}

Received 16 October 2013

Received in revised form 23 April 2014

Accepted 19 June 2014

Available online xxx

\section{Keywords:}

Sediment-bound organic matter

Sources

Carbon and nitrogen stable isotopes

Near infra-red reflectance spectroscopy

Salmonids

Farm manures

\begin{abstract}
A B S T R A C T
The biodegradation of organic matter ingressing spawning gravels in rivers exerts an oxygen demand which is believed to contribute to detrimental impacts on aquatic ecology including salmonids. Catchment management strategies therefore require reliable information on the key sources of sediment-bound organic matter. Accordingly, a novel source fingerprinting procedure based on analyses of bulk stable ${ }^{13} \mathrm{C}$ and ${ }^{15} \mathrm{~N}$ isotope values and organic molecular structures detected using near infrared reflectance (NIR) spectroscopy was tested for assessing the primary sources of sediment-bound organic matter infiltrating artificial Atlantic salmon spawning redds in five rivers across England and Wales. Statistically-verified source fingerprints were identified using a combination of the Kruskal-Wallis $\mathrm{H}$ test, principal component analysis and GA-driven discriminant function analysis. Interstitial sediment samples were obtained from artificial redds using retrievable basket traps inserted at the start of the salmonid spawning season and extracted subsequently in conjunction with critical juvenile phases (eyeing, hatch, emergence, late spawning) of fish development associated with incubation and emergence. Over the duration of these four basket extractions, the overall relative frequency-weighted average median source contributions to the interstitial sediment-bound organic matter sampled in the study rivers ranged between $26 \%$ (full uncertainty range $0-100 \%$ ) and $44 \%$ (full uncertainty range $0-100 \%$ ) for farm yard manures/slurries, $11 \%$ (full uncertainty range $0-75 \%$ ) and $48 \%$ (full uncertainty range $0-99 \%$ ) for damaged road verges, $16 \%$ (full uncertainty range (0-78\%) and $52 \%$ (full uncertainty range $(0-100 \%)$ for decaying instream vegetation and $4 \%$ (full uncertainty range $0-31 \%$ ) and $10 \%$ (full uncertainty range $(0-44 \%)$ for human septic waste. The results of mass conservation tests suggest that the procedure combining bulk ${ }^{13} \mathrm{C}$ and ${ }^{15} \mathrm{~N}$ isotope values and NIR spectroscopy data on organic molecular structures is sensitive to the risks of significant non-conservative tracer behaviour in the fluvial environment and will therefore not necessarily work at all in-channel sites in all catchments.
\end{abstract}

(c) 2014 Elsevier B.V. All rights reserved.

\section{Introduction}

The quality of hyporheic river water exerts an important control on aquatic ecology by influencing many in-channel ecological processes including biogeochemical processing (Boulton et al., 1998; Duff and Triska, 2000; Storey et al., 2004). A particularly important linkage between hyporheic water quality and aquatic

\footnotetext{
* Corresponding author at: Rothamsted Research, Sustainable Soils and Grassland Systems Department, North WykeOkehampton, Devon EX20 2SB, UK.

Tel.: +44 1837883515 .

E-mail address: adrian.collins@rothamsted.ac.uk (A.L. Collins).
}

ecology is represented by the issue of low dissolved oxygen supply in the benthic zone (Malard and Hervant, 1999; Finn, 2007). In this regard, a specific area that has been studied intensively is the effect of low dissolved oxygen supply on the survival of salmonid embryos incubating in river spawning beds (Chevalier et al., 1984; Peterson and Quinn, 1996; Rubin and Glimsater, 1996; Malcolm et al., 2003; Armstrong et al., 2003; Youngson et al., 2004; Greig et al., 2006; Sear et al., 2013). Incubating salmonids spend a period of months (typically 4-6) in the hyporheic zone between oviposition and emergence or 'swim up', and transient episodes of de-oxygenation have been identified as the cause of sub-lethal or lethal outcomes which ultimately impact on recruitment to populations (Youngson et al., 2004; Malcolm et al., 2008). 
Episodes of low dissolved oxygen supply in the benthos have been attributed to various causes including groundwater upwelling (Malcolm et al., 2003), reduced gravel permeability due to fine sediment ingress (Lisle, 1989; Zimmerman and Lapointe, 2005) which can hamper the removal of toxic metabolic products (Shumway et al., 1964) and enhanced oxygen consumption arising from the infiltration of fine particulate organic matter (Greig et al., 2006; Malcolm et al., 2008; Soulsby et al., 2009; Sear et al., 2013). More specifically, sediment-bound organic matter influences dissolved oxygen supply to incubating progeny in the spawning substrate via two principal mechanisms: direct competition from microorganisms during organic matter decomposition, and; the growth of biofilms which hamper intragravel flow and oxygen availability and may also scavenge potentially toxic substances (House, 2003; Greig et al., 2007; Sader et al., 2011).

Given increased recognition of the potential for sedimentbound organic matter to contribute to the degradation of salmonid spawning habitats, management strategies require a reliable evidence base on the key sources of this specific problem to ensure effective targeting of interventions (Collins et al., 2009). Previous work has, however, predominantly focussed on understanding the key sources of minerogenic fine sediment infiltrating spawning substrates (Walling et al., 2003; Collins et al., 2010a, 2012a). More recently, Collins et al. (2013) reported the application of a source fingerprinting procedure specifically for the sedimentbound organic matter ingressing salmonid spawning gravels in the River Blackwater catchment, in southern England. Given the initial success of that study, it was considered useful to apply and test the sourcing procedure elsewhere and to continue refining it. On that basis, the specific objectives of this second study were:

- To extend the application of a composite fingerprinting procedure combining the use of bulk stable ${ }^{13} \mathrm{C}$ and ${ }^{15} \mathrm{~N}$ isotope values and NIR spectra to five new study rivers across England and Wales to test its wider applicability for distinguishing and apportioning the primary sources (farm manures/slurries, damaged road verges, instream decaying vegetation and human septic waste) of sediment-bound organic matter infiltrating salmonid spawning gravels.

- To use the outputs where the expanded application of the tracing procedure was successful to deliver hitherto unavailable evidence on the relative contributions of the different sources to the sediment-bound organic matter infiltrating salmonid spawning gravels.

\section{Study catchments}

The location of the study catchments is presented in Fig. 1. Table 1 provides summary information on a number of catchment attributes including area, land cover, stocking densities, applications of organic carbon to farm land in association with manure/ slurry spreading and the estimated number of domestic properties unconnected to mains sewage and therefore assumed to have septic tanks. All study sites were known spawning grounds of Atlantic salmon (Salmo salar).

\section{Methods}

3.1. Catchment sampling to characterise potential sources of the sediment-bound organic matter infiltrating salmonid spawning gravels

Spatially representative source material samples for the sediment-bound organic matter infiltrating salmonid spawning gravels were collected during the autumn and winter of 2010. This

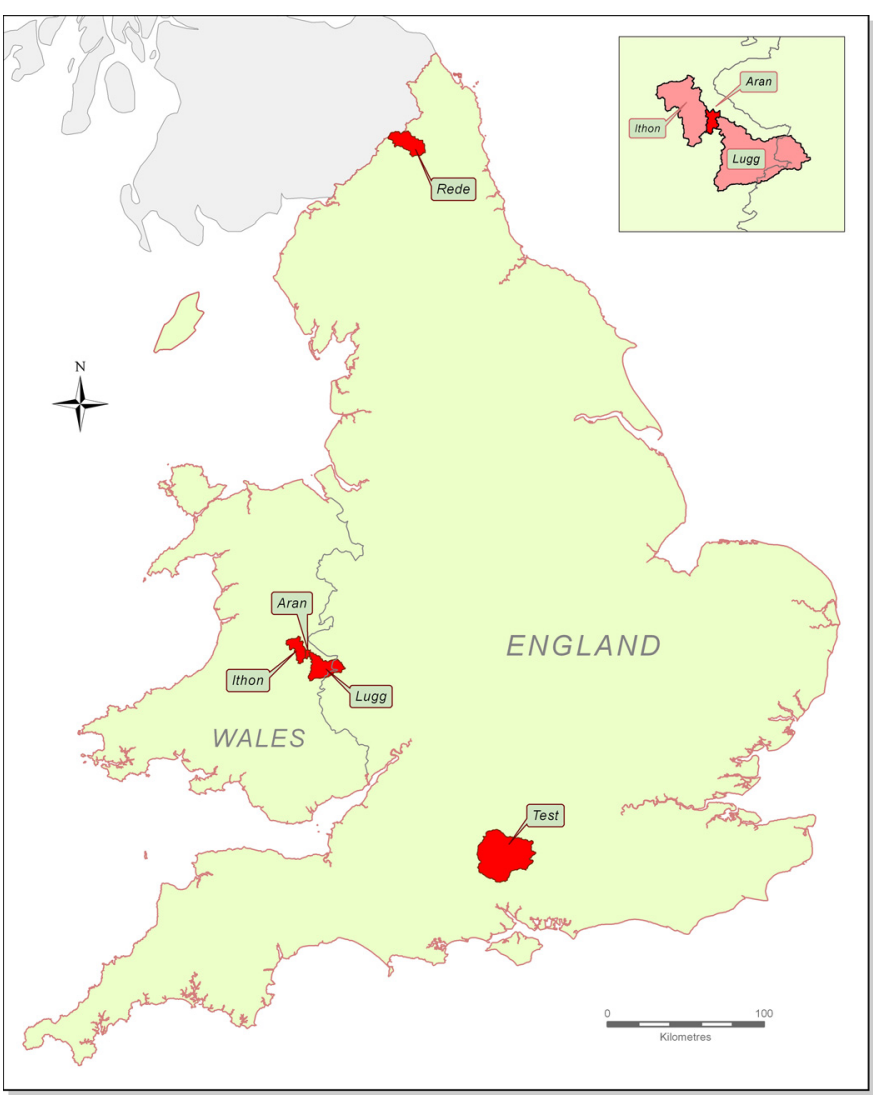

Fig. 1. The location of the five study catchments across England and Wales.

sampling encompassed farm yard manure/slurries, damaged road verges, instream decaying vegetation and point sources in the form of septic tanks and sewage treatment works. 10 composite samples (each comprising 10 sub-samples) were collected for each source

Table 1

Background information for the study catchments and sampling sites.

\begin{tabular}{|c|c|c|c|c|c|}
\hline Attribute & $\begin{array}{l}\text { River } \\
\text { Aran }\end{array}$ & $\begin{array}{l}\text { River } \\
\text { Ithon }\end{array}$ & $\begin{array}{l}\text { River } \\
\text { Lugg }\end{array}$ & $\begin{array}{l}\text { River } \\
\text { Rede }\end{array}$ & $\begin{array}{l}\text { River } \\
\text { Test }\end{array}$ \\
\hline Area $\left(\mathrm{km}^{2}\right)$ & 12 & 32 & 230 & 214 & 104 \\
\hline$\%$ Urban $^{a}$ & 0 & 1 & 4 & 1 & 8 \\
\hline$\%$ Water $^{\mathrm{a}}$ & 1 & 1 & 1 & 1 & 0 \\
\hline$\%$ Woodland $^{\mathrm{a}}$ & 0 & 4 & 16 & 29 & 15 \\
\hline$\%$ Rough pasture ${ }^{a}$ & 47 & 13 & 9 & 48 & 10 \\
\hline$\%$ Improved pasture ${ }^{a}$ & 51 & 80 & 58 & 21 & 16 \\
\hline$\%$ Arable $^{a}$ & 1 & 1 & 12 & 0 & 51 \\
\hline $\begin{array}{l}\text { Average annual rainfall (1961-1990; } \\
\text { mm })^{\mathrm{a}}\end{array}$ & 1086 & 1086 & 748 & 941 & 576 \\
\hline $\begin{array}{l}\text { Unconnected properties (count/ } \\
\mathrm{km}^{2} \text { ) }\end{array}$ & 1.4 & 2.0 & 3.8 & 0.2 & 11.9 \\
\hline Cattle (heads/ha) ${ }^{\mathrm{a}}$ & 25 & 40 & 44 & 10 & 12 \\
\hline Sheep and lambs (heads/ha) ${ }^{a}$ & 876 & 852 & 670 & 175 & 44 \\
\hline Pigs (heads/ha) ${ }^{a}$ & 0 & 1 & 1 & 2 & 14 \\
\hline Poultry (heads per ha) ${ }^{a}$ & 318 & 807 & 1789 & 1 & 1103 \\
\hline $\begin{array}{l}\text { Organic carbon loading to land from } \\
\text { farm manures }\left(\mathrm{t} \mathrm{km}^{-2} \mathrm{yr}^{-1}\right)^{\mathrm{b}}\end{array}$ & 591 & 565 & 637 & 140 & 167 \\
\hline Surface bed material $D_{50}(\mathrm{~mm})^{c}$ & 24.0 & 45.5 & 43.2 & 46.0 & 28.4 \\
\hline Surface bed material $D_{95}(\mathrm{~mm})^{\mathrm{c}}$ & 34.7 & 62.4 & 58.5 & 59.1 & 55.6 \\
\hline Subsurface bed material $D_{50}(\mathrm{~mm})^{\mathrm{c}}$ & 10.4 & 11.9 & 31.4 & 26.9 & 6.3 \\
\hline Subsurface bed material $D_{95}(\mathrm{~mm})^{\mathrm{c}}$ & 34.3 & 42.3 & 63.2 & 54.3 & 37.0 \\
\hline$\%$ Sand $^{\mathrm{C}}$ & 15.9 & 22.5 & 9.6 & 12.4 & 25.0 \\
\hline$\%$ Silt/clay ${ }^{\mathrm{c}}$ & 4.7 & 6.3 & 5.0 & 10.5 & 7.3 \\
\hline
\end{tabular}

a ADAS land use database 2010 (see Comber et al., 2008 for background information).

b Based on ADAS manures GIS tool.

c Based on field survey data. 
category, thereby yielding an overall total of 40 bulked samples comprising 400 sub-samples for each of the five study rivers. Farm yard manure/slurry samples included fresh excreta from yards, steadings and housings, as well as material from field heaps and dry or wet stores. Cattle, sheep, poultry and pig enterprises present in the study areas were included in the sampling campaigns. The random sub-sampling ( $n=10$ sub-samples per composite sample) was designed to be spatially representative of each yard, steading, field heap, store or housing in question. Representative samples of damaged road verges were retrieved from $100 \mathrm{~m}$ sections of road margins exhibiting erosion and selected randomly to be representative of the entire road network in each study catchment. These samples combined the mulch and leaf litter observed in damaged road margins degraded by vehicle or livestock traffic. Samples of instream decaying vegetation were collected along the channel system from specific $100 \mathrm{~m}$ reaches selected randomly along the channel network of the study rivers. These source samples included leaf and stem litter (e.g. from decaying riparian vegetation and macrophytes) trapped by coarse woody debris and additional obstacles such as the pillars of bridges. 10 replicate sub-samples were collected from the settling chambers or drainage field biomat of individual septic tank installations and bulked into a single composite. All source material samples were placed in cool boxes with ice packs immediately following collection in the field and remained in such storage during transportation to the laboratory (typically on the same day) for the analysis of potential fingerprint properties.

\subsection{Sampling the sediment-bound organic matter infiltrating artificial salmonid redds using retrievable basket traps}

Disturbance of natural redds is prohibited in the UK given the conservation status of Atlantic salmon. As a result, scientific studies have tended to use artificially-constructed redds (e.g. Acornley and Sear, 1999; Walling et al., 2003; Greig et al., 2007; Collins et al., 2010a, 2012a). Representative samples of interstitial sediment were collected from spawning gravels at the outlets of the five study catchments (Fig. 1 ) using mesh retrievable basket traps $(n=12$ per river; cf. Walling et al., 2003; Collins et al., 2010a, 2013; diameter = $12 \mathrm{~cm}$, depth $=20 \mathrm{~cm}$ ). Redd depressions or 'pots' were created in riffles used for spawning with a spade and pick axe. Extracted gravel was moved downstream during the cutting of the artificial redds, thereby creating the characteristic tail spills. After the insertion of the mesh traps, the river bed immediately upstream of each artificial redd was cut to create the cleaned gravel hump and upstream shallow depression characteristic of natural redds. Timeintegrating basket traps were inserted in the artificial redds in early December 2010 after being filled with clean local framework gravel (> $6 \mathrm{~mm}$; cf. Crisp and Carling, 1989). These traps sampled particulate material infiltration to the typical depth $(\sim 15-20 \mathrm{~cm})$ used by Atlantic salmon in burying their eggs for incubation. Each basket trap comprised an outer bag (UK supermarket green bag) which was retracted around the base prior to emplacement, but raised again during extraction from the river substrate to prevent the winnowing of interstitial material collected during the sampling period. The basket traps were located at the end of their deployment using coloured strings attached to their upper rims. Three random baskets were extracted from the outlet sampling location on each study river on each of four occasions; February, March, April and May 2011. These extractions were aligned with the key embryonic and early life stages of salmonids, namely eyeing, hatch, emergence and late spawning, respectively (cf. Collins et al., 2013). Following exhumation, the framework and interstitial material in the basket traps were separated in situ on the river bank using a $500 \mu \mathrm{m}$ sieve. The $<500 \mu \mathrm{m}$ interstitial fines were immediately placed in a cool box and subsequently transported to the laboratory.

\subsection{Sample preparation and laboratory analyses for fingerprint properties}

All source material samples were oven dried $\left(40^{\circ} \mathrm{C}\right)$ on trays, milled to $1 \mathrm{~mm}$ and sieved using a $63 \mu \mathrm{m}$ mesh; stones were removed to avoid damage to the mill. Samples of interstitial material from the sediment basket traps were wet sieved with river water using a cascade of two apertures $(250 \mu \mathrm{m}$ and $63 \mu \mathrm{m})$ and subsequently oven dried $\left(40^{\circ} \mathrm{C}\right)$. Both source and sediment samples were ground to a fine powder prior to analysis for \% total organic carbon (TOC) and total nitrogen (TN). Stable isotope determinations of bulk $\delta^{13} \mathrm{C}$ and $\delta^{15} \mathrm{~N}$ values were undertaken using a Carlo Erba NA2000 analyser (CE Instruments, Wigan, UK) and a SerCon 20-22 isotope ratio mass spectrometer (SerCon Ltd., Crewe, UK). Wheat flour (1.91\% N, 41.81\% C, $4.8 \delta^{15} \mathrm{~N}$ and -26.4 $\delta^{13} \mathrm{C}$ ) calibrated against IAEA-N-1 by Iso-Analytical, Crewe, UK was used as a reference standard. The natural abundance stable isotope values were expressed using the standard $\delta$ notation with respect to the reference materials.

NIR spectroscopy provides a rapid, non-destructive simultaneous analytical procedure for multiple analytes, requiring minimal sample preparation (cf. Blanco and Villarroya, 2002; Pellicer and Bravo, 2011; Wessels et al., 2011). A Thermo Scientific Antaris 1 analyser which provided a spectral range of 4000$10,000 \mathrm{~cm}^{-1}$, and 32 scans per sample with a typical resolution of $8 \mathrm{~cm}^{-1}$, was used to measure NIR spectra on the $<63 \mu \mathrm{m}$ dried samples. All source and sediment samples were run in triplicate with the average of these repeat runs used in subsequent statistical analysis and numerical modelling. No reagents were used in conjunction with the NIR analyses. The NIR diffuse reflectance spectra provided information on the overall biochemical composition of the solid samples (cf. Foley et al., 1998; Richardson et al., 2003). NIR spectra comprise overtones and absorption bands (Esteve Agelet and Hurburgh, 2010). Overtones represent electron excitations to higher energy levels and the spectra comprise three main overtones with the absorption bands decreasing with overtone level (i.e. from 1 to 3 ).

\subsection{Processing the fingerprint property data}

The processing of the fingerprint property data provided by the laboratory analyses relied on the fundamental components of the statistical and modelling framework reported recently by Collins et al. (2010b, 2012b, 2013).

\subsubsection{Testing the mass conservation of the fingerprint properties for sediment-bound organic matter}

Fingerprint properties must be conservative during delivery from catchment sources to the sampling point in the river channel to be used in the numerical mass balance modelling for source apportionment. Failure to remove non-conservative properties will generate unacceptably high errors. A so-called range test is applied to screen the data by comparing the source and sediment values of each property. Fingerprint properties are assumed to be sufficiently conservative if the values measured for the interstitial sediment samples plot within the polygon or mixing space bounded by the ranges of the corresponding values for the individual sources in the same catchment. The results of the mass conservation test for the bulk ${ }^{13} \mathrm{C}$ and ${ }^{15} \mathrm{~N}$ isotope values measured for each of the five study catchments are presented in Table 2. Only the dataset for the River Lugg study area passed the range test in the case of the bulk $\delta^{13} \mathrm{C}$ isotope values, whereas the $\delta^{15} \mathrm{~N}$ isotope values for all five study rivers passed the mass conservation test.

A visual comparison of the measured median NIR spectra measured for the organic matter sources and interstitial sediment samples from each study catchment is presented in Fig. 2. These 
Table 2

Comparison of the carbon and nitrogen stable isotope values measured for the source and interstitial samples (showing the raw measured (max, min, median) values and corrections to the median measured values using $Q_{\mathrm{n}}$ and a within-source variation weighting used in the mass balance modelling; values in bold represent the highest and lowest source values plus or minus $Q_{n}$ and corrected for the within-source variation weighting delineating the source mixing polygon, and the highest and lowest interstitial sediment values from the same study catchment for the purpose of assessing mass conservation).

\begin{tabular}{|c|c|c|c|c|c|c|c|c|c|c|}
\hline Catchment source/interstitial sediment & $\begin{array}{l}\text { River } \\
\text { Aran } \\
\delta^{13} \mathrm{C} \\
(\%)\end{array}$ & $\begin{array}{l}\text { River } \\
\text { Aran } \\
\delta^{15} \mathrm{~N} \\
(\%)\end{array}$ & $\begin{array}{l}\text { River } \\
\text { Ithon } \\
\delta^{13} \mathrm{C} \\
(\% o)\end{array}$ & $\begin{array}{l}\text { River } \\
\text { Ithon } \\
\delta^{15} \mathrm{~N} \\
(\% o)\end{array}$ & $\begin{array}{l}\text { River } \\
\text { Lugg } \\
\delta^{13} \mathrm{C} \\
(\%)\end{array}$ & $\begin{array}{l}\text { River } \\
\text { Lugg } \\
\delta^{15} \mathrm{~N} \\
(\%)\end{array}$ & $\begin{array}{l}\text { River } \\
\text { Rede } \\
\delta^{13} \mathrm{C} \\
(\%)\end{array}$ & $\begin{array}{l}\text { River } \\
\text { Rede } \\
\delta^{15} \mathrm{~N} \\
(\%)\end{array}$ & $\begin{array}{l}\text { River } \\
\text { Test } \\
\delta^{13} \mathrm{C} \\
(\%)\end{array}$ & $\begin{array}{l}\text { River } \\
\text { Test } \\
\delta^{15} \mathrm{~N} \\
(\% \circ)\end{array}$ \\
\hline Farm yard manure/slurries (max) & -23.0 & 8.7 & -28.6 & 11.4 & -22.1 & 9.5 & -27.5 & 8.4 & -19.6 & 12.2 \\
\hline Farm yard manure/slurries (min) & -29.2 & 5.3 & -29.7 & 4.2 & -29.0 & 6.7 & -30.0 & 5.9 & -29.0 & 4.7 \\
\hline Farm yard manure/slurries (median) & -28.1 & 7.8 & -29.2 & 6.6 & -25.9 & 8.9 & -28.4 & 7.6 & -27.2 & 7.6 \\
\hline Farm yard manure/slurries $\left(Q_{n}\right)$ & 1.1 & 0.8 & 0.3 & 1.5 & 2.4 & 0.3 & 0.8 & 0.8 & 1.6 & 1.6 \\
\hline Farm yard manure/slurries (within source variation weighting) & 1.000 & 1.000 & 1.024 & 1.024 & 1.066 & 1.066 & 1.000 & 1.000 & 1.000 & 1.000 \\
\hline $\begin{array}{l}\text { Farm yard manure/slurries (median }+Q_{\mathrm{n}}{ }^{*} \text { within source variation } \\
\text { weighting }\end{array}$ & -29.2 & 8.6 & -30.2 & 8.2 & -30.2 & 9.9 & -29.2 & 8.4 & $-\mathbf{2 8 . 8}$ & 9.2 \\
\hline $\begin{array}{l}\text { Farm yard manure/slurries (median }-Q_{n}{ }^{*} \text { within source } \\
\text { variation weighting }\end{array}$ & -27.0 & 7.0 & -29.6 & 5.2 & -25.1 & 9.2 & -27.6 & 6.8 & -25.7 & 6.0 \\
\hline Damaged road verges (max) & -27.2 & 6.1 & -27.2 & 3.4 & -25.4 & 4.5 & -25.8 & 4.5 & -24.5 & 5.1 \\
\hline Damaged road verges (min) & -29.9 & 1.6 & -29.8 & 0.4 & -26.8 & 0.3 & -29.5 & 1.2 & -28.4 & 0.1 \\
\hline Damaged road verges (median) & -28.8 & 2.9 & -28.7 & 2.1 & -26.0 & 1.2 & -28.0 & 2.9 & -27.7 & 2.9 \\
\hline Damaged road verges $\left(Q_{n}\right)$ & 0.5 & 1.2 & 0.8 & 0.8 & 0.4 & 0.6 & 1.3 & 1.0 & 0.6 & 1.1 \\
\hline Damaged road verges (within source variation weighting) & 1.023 & 1.023 & 1.000 & 1.000 & 1.000 & 1.000 & 1.036 & 1.036 & 1.018 & 1.018 \\
\hline $\begin{array}{l}\text { Damaged road verges (median }+Q_{\mathrm{n}}{ }^{*} \text { within source variation } \\
\text { weighting) }\end{array}$ & -29.9 & 4.1 & -29.5 & 2.9 & -26.4 & 1.8 & -30.4 & 4.0 & -28.8 & 4.1 \\
\hline $\begin{array}{l}\text { Damaged road verges (median }-Q_{\mathrm{n}}{ }^{*} \text { within source variation } \\
\text { weighting) }\end{array}$ & -28.9 & 1.7 & -28.0 & 1.3 & -25.6 & 0.7 & -27.7 & 2.0 & -27.5 & 1.8 \\
\hline Instream decaying vegetation (max) & -28.4 & 3.0 & -28.6 & 4.1 & -27.9 & 4.3 & -27.8 & 3.5 & -27.9 & 4.9 \\
\hline Instream decaying vegetation (min) & -31.0 & 0.1 & -30.5 & 0.7 & -30.6 & 0.1 & -31.5 & 0.5 & -30.4 & 1.1 \\
\hline Instream decaying vegetation (median) & -29.3 & 1.2 & -29.6 & 2.4 & -29.4 & 2.8 & -30.4 & 1.7 & -29.5 & 2.7 \\
\hline Instream decaying vegetation (Qn) & 0.3 & 1.0 & 0.6 & 1.4 & 1.0 & 1.3 & 1.0 & 1.2 & 0.3 & 1.1 \\
\hline $\begin{array}{l}\text { Instream decaying vegetation (within source variation } \\
\text { weighting) }\end{array}$ & 1.177 & 1.177 & 1.023 & 1.023 & 1.018 & 1.018 & 1.012 & 1.012 & 1.031 & 1.031 \\
\hline $\begin{array}{l}\text { Instream decaying vegetation (median }+Q_{n}{ }^{*} \text { within source } \\
\text { vegetation weighting) }\end{array}$ & -34.9 & 2.6 & -30.9 & 3.9 & -30.9 & 4.1 & -31.8 & 2.9 & -30.7 & 3.9 \\
\hline $\begin{array}{l}\text { Instream decaying vegetation (median }-Q_{n}{ }^{*} \text { within source } \\
\text { vegetation weighting) }\end{array}$ & -34.2 & 0.2 & -29.6 & 1.0 & -28.9 & 1.5 & -29.8 & 0.5 & -30.1 & 1.7 \\
\hline Human septic waste (max) & -25.9 & 11.5 & -25.0 & 11.9 & -25.1 & 11.8 & -26.9 & 12.5 & -25.1 & 11.0 \\
\hline Human septic waste (min) & -27.1 & 9.5 & -27.7 & 9.0 & -28.0 & 9.9 & -27.9 & 9.0 & -26.7 & 8.5 \\
\hline Human septic waste (median) & -26.7 & 10.3 & -26.0 & 10.6 & -26.2 & 11.0 & -25.5 & 11.3 & -27.0 & 11.6 \\
\hline Human septic waste (Qn) & 0.4 & 0.2 & 0.5 & 0.3 & 0.6 & 0.4 & 0.4 & 0.3 & 0.2 & 0.2 \\
\hline Human septic waste (within source variation weighting) & 1.175 & 1.117 & 1.185 & 1.135 & 1.211 & 1.192 & 1.181 & 1.134 & 1.145 & 1.056 \\
\hline $\begin{array}{l}\text { Human septic waste (median }+Q_{\mathrm{n}}{ }^{*} \text { within source variation } \\
\text { weighting) }\end{array}$ & -31.9 & 11.8 & -30.2 & 12.4 & -31.0 & 13.6 & -29.6 & 13.2 & -31.1 & 12.5 \\
\hline $\begin{array}{l}\text { Human septic waste (median }-Q_{n}{ }^{*} \text { within source variation } \\
\text { weighting) }\end{array}$ & -30.9 & 11.3 & -31.4 & 11.7 & -32.5 & 12.6 & -30.6 & 12.5 & -30.7 & 12.0 \\
\hline Interstitial sediment (max) & -27.6 & 3.5 & -26.9 & 3.8 & -26.3 & 6.8 & -22.5 & 3.9 & v17.0 & 5.9 \\
\hline Interstitial sediment (min) & -28.0 & 3.3 & -27.6 & 4.4 & -27.5 & 3.9 & -28.5 & 3.6 & -18.3 & 5.3 \\
\hline Interstitial sediment (median) & -27.7 & 3.4 & -27.1 & 3.9 & -27.2 & 4.2 & -25.0 & 6.4 & -17.6 & 5.8 \\
\hline Interstitial sediment (Qn) & 0.1 & 0.1 & 0.2 & 0.2 & 0.3 & 0.5 & 6.6 & 3.1 & 0.1 & 0.3 \\
\hline Interstitial sediment (median $\left.+Q_{n}\right)$ & -27.8 & 3.5 & -27.2 & 4.1 & -27.5 & 4.7 & -31.7 & 9.5 & -17.7 & 6.1 \\
\hline Interstitial sediment (median $\left.-Q_{n}\right)$ & -27.6 & 3.3 & -26.9 & 3.8 & -26.9 & 3.7 & -18.4 & 3.3 & -17.5 & 5.5 \\
\hline
\end{tabular}

plots demonstrated that the absorbance values for organic structures identified using NIR spectroscopy on the interstitial sediment samples collected from the River Aran and Test catchments were outside the corresponding range measured for the four sources. On this basis, these data could not be used to assess the sources of sediment-bound organic matter using a mass balance modelling approach. In the case of the remaining three study catchments, only parts of the NIR spectra passed the mass conservation test (Fig. 2). Only those parts of the NIR spectra measured for the River Ithon, Lugg and Rede catchments passing the range test were appropriate for inclusion in the statistical analysis and numerical mass balance modelling for source ascription.

\subsubsection{Discrimination of the sources of sediment-bound organic matter} infiltrating artificial salmonid redds using statistically-verified composite signatures

The discrimination of the source end members for the sediment-associated organic matter ingressing the artificial salmonid redds was based on the procedure reported in Collins et al. (2013). This procedure combines application of the KruskalWallis $H$-test (KW-H), principal component analysis (PCA) and GAdriven discriminant function analysis (GA-DFA). Table 3 presents the results of the KW-H tests. Properties passing the $\mathrm{KW}-\mathrm{H}$ tests were used in the GA-DFA to identify optimum signatures and the discriminatory power of these composite fingerprints ranged from 95\% for the River Lugg study catchment to $98 \%$ for the River Ithon and Rede study areas (Table 4). All three optimum signatures identified using those properties passing the $\mathrm{KW}-\mathrm{H}$ tests included a combination of bulk $\delta^{13} \mathrm{C}$ and $\delta^{15} \mathrm{~N}$ values and molecular structures identified within the NIR spectra. The corresponding results for the PCA are shown in Tables 5 and 6. Loadings associated with two principal components explained $99.8 \%$ of the variance in source end member samples collected from the River Lugg study catchment compared with $100 \%$ of those collected from the remaining two study areas (Table 5). The optimum PCA composite signatures (Table 6) distinguished between 95 and $100 \%$ of the samples collected to represent the sources of interstitial sediment-associated organic matter and comprised both bulk $\delta^{13} \mathrm{C}$ and $\delta^{15} \mathrm{~N}$ values and components of the NIR spectra. Three 

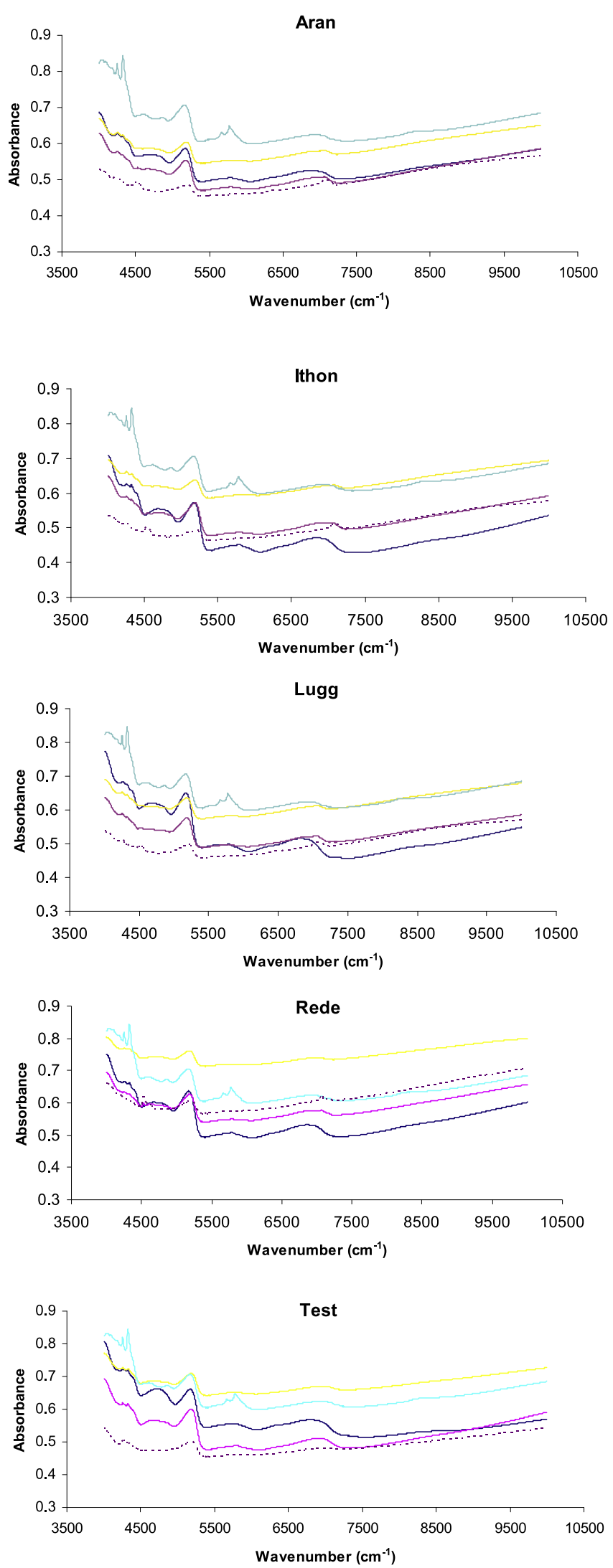

Fig. 2. Comparison of the median NIR spectra measured for the source and interstitial sediment samples from each of the five study catchments (dark blue line - farm yard manure/slurries, pink line - decaying instream vegetation, yellow line - damaged road verges, light blue line - human septic waste, purple dashed line interstitial sediment). (For interpretation of the references to colour in this figure legend, the reader is referred to the web version of this article.) optimum signatures were identified for each study catchment using GA-DFA (Table 7) and these classified between 95 and $100 \%$ of the source samples into the correct source groups. Only in the case of the River Ithon study area did the GA-DFA optimum signatures not contain bulk isotope values (Table 7).

The statistical analysis of the tracer data demonstrated clearly that a combination of bulk stable isotope analysis and NIR spectra provides a powerful means of discriminating catchment source end members for sediment-associated organic matter. A number of studies have investigated the application of bulk $\delta^{13} \mathrm{C}$ and $\delta^{15} \mathrm{~N}$ values as natural tracers for discriminating particulate matter originating from various sources in river catchments (e.g. Papanicolaou et al., 2003; Dazell et al., 2005; Guo and Macdonald, 2006; Fox and Papanicolaou, 2008; Fox, 2009; Jacinthe et al., 2009; Fox et al., 2010; Mukundan et al., 2010, 2012; Jankowski et al., 2012). The isotopic ranges in Table 2 for the farm yard manure/ slurry samples reflected those typically reported for grass $\left(\delta^{13} \mathrm{C}=\right.$ -27 to $-31 \%$, $\delta^{15} \mathrm{~N}=7-12 \%$; Glaser et al., 2001; Dungait et al., 2005, 2010; Lynch et al., 2006; Kriszan et al., 2009) and maize $\left(\delta^{13} \mathrm{C}=-13\right.$ to $-21 \%$, $\delta^{15} \mathrm{~N}=7-14 \%$; Glaser et al., 2001; Dungait et al., 2005, 2010) fodder based systems. The maximum $\delta^{13} \mathrm{C}$ values in the farm yard manure and slurries collected from the Aran, Lugg and Test catchments suggest input from livestock fed a maize diet, which may be the source of the ${ }^{13} \mathrm{C}$-enriched values in the interstitial sediments sampled from the artificial redds of the Rede and Test (although local direct inputs from soils under maize cultivation cannot be ruled out). Although overlap between the bulk isotopic values measured for different sources is common (Michener and Lajtha, 2007; Xiao and Liu, 2010), isotopic datasets frequently distinguish various sources, especially when combined

Table 3

The results of the KW-H test for discriminating the sources of the interstitial sediment-bound organic matter using individual fingerprint properties.

\begin{tabular}{|c|c|c|c|c|c|c|c|}
\hline Property & Overtone & $\begin{array}{l}H- \\
\text { value }\end{array}$ & $\begin{array}{l}p- \\
\text { value }\end{array}$ & Property & Overtone & $\begin{array}{l}H- \\
\text { value }\end{array}$ & $p$-value \\
\hline \multicolumn{8}{|l|}{ ITHON } \\
\hline$\delta^{15} \mathrm{~N}$ & & 31.0 & 0.000 & $\begin{array}{l}\text { Starch, } \\
\text { glucose }\end{array}$ & 2 & 31.9 & 0.000 \\
\hline $\mathrm{ArOH}$ & 2 & 32.3 & 0.000 & $\mathrm{ArNH}_{2}$ & 3 & 31.7 & 0.000 \\
\hline Aromatic & 2 & 32.8 & 0.000 & $\mathrm{ArOH}$ & 3 & 31.6 & 0.000 \\
\hline $\mathrm{C}-\mathrm{H}$ & 2 & 31.8 & 0.000 & Aromatic & 3 & 32.5 & 0.000 \\
\hline $\mathrm{CH}$ & 2 & 32.0 & 0.000 & $\mathrm{CH}$ & 3 & 32.5 & 0.000 \\
\hline $\mathrm{CH}_{2}$ & 2 & 32.9 & 0.000 & $\mathrm{CH}_{2}$ & 3 & 32.6 & 0.000 \\
\hline $\mathrm{CH}_{3}$ & 2 & 32.5 & 0.000 & $\mathrm{CH}_{3}$ & 3 & 33.3 & 0.000 \\
\hline $\mathrm{RNH}_{2}$ & 2 & 31.8 & 0.000 & $\mathrm{HC}=\mathrm{CH}$ & 3 & 33.3 & 0.000 \\
\hline $\mathrm{ROH}$ & 2 & 32.5 & 0.000 & Protein & 3 & 31.6 & 0.000 \\
\hline Starch & 2 & 32.1 & 0.000 & $\mathrm{RNH}_{2}$ & 3 & 31.8 & 0.000 \\
\hline \multicolumn{8}{|l|}{ LUGG } \\
\hline$\delta^{13} \mathrm{C}$ & & 24.8 & 0.000 & $\mathrm{CH}_{2}$ & 3 & 27.6 & 0.000 \\
\hline$\delta^{15} \mathrm{~N}$ & & 33.0 & 0.000 & $\mathrm{CH}_{3}$ & 3 & 28.5 & 0.000 \\
\hline $\mathrm{ArNH}_{2}$ & 3 & 27.1 & 0.000 & $\mathrm{HC}=\mathrm{CH}$ & 3 & 26.0 & 0.000 \\
\hline Aromatic & 3 & 26.1 & 0.000 & Protein & 3 & 26.1 & 0.000 \\
\hline $\mathrm{CH}$ & 3 & 25.7 & 0.000 & $\mathrm{RNH}_{2}$ & 3 & 26.2 & 0.000 \\
\hline \multicolumn{8}{|l|}{ REDE } \\
\hline$\delta^{15} \mathrm{~N}$ & & 33.5 & 0.000 & $\mathrm{ROH}$ & 2 & 31.6 & 0.000 \\
\hline $\mathrm{ArNH}_{2}$ & 2 & 29.5 & 0.000 & Starch & 2 & 32.0 & 0.000 \\
\hline $\mathrm{ArOH}$ & 2 & 28.2 & 0.000 & $\begin{array}{l}\text { Starch, } \\
\text { glucose }\end{array}$ & 2 & 30.3 & 0.000 \\
\hline Aromatic & 2 & 30.5 & 0.000 & $\mathrm{ArNH}_{2}$ & 3 & 24.7 & 0.000 \\
\hline $\mathrm{C}-\mathrm{H}$ & 2 & 29.4 & 0.000 & $\mathrm{ArOH}$ & 3 & 23.4 & 0.000 \\
\hline Cellulose & 2 & 33.3 & 0.000 & Aromatic & 3 & 26.3 & 0.000 \\
\hline $\mathrm{CH}$ & 2 & 29.4 & 0.000 & $\mathrm{CH}$ & 3 & 28.2 & 0.000 \\
\hline $\mathrm{CH}_{2}$ & 2 & 32.3 & 0.000 & $\mathrm{CH}_{2}$ & 3 & 26.9 & 0.000 \\
\hline $\mathrm{CH}_{3}$ & 2 & 33.4 & 0.000 & $\mathrm{CH}_{3}$ & 3 & 29.6 & 0.000 \\
\hline $\mathrm{CONH}_{2}$ & 2 & 33.1 & 0.000 & $\mathrm{HC}=\mathrm{CH}$ & 3 & 26.0 & 0.000 \\
\hline CONHR & 2 & 29.0 & 0.000 & Protein & 3 & 23.9 & 0.000 \\
\hline Protein & 2 & 30.9 & 0.000 & $\mathrm{RNH}_{2}$ & 3 & 24.7 & 0.000 \\
\hline $\mathrm{RNH}_{2}$ & 2 & 29.25 & 0.00 & & & & \\
\hline
\end{tabular}


with alternative fingerprint properties as composite signatures (e.g. Collins et al., 2013). A number of studies have previously used NIR spectroscopy to assess the physical and chemical properties of catchment source materials by linking the spectra with regression models for predicting mineralogical and organic matter (e.g. Hillier, 2001; Poulenard et al., 2009, 2012) or geochemical constituents (Elliott et al., 2007; Martínez-Carreras et al., 2010). In this study, however, the absorbance values of the peaks in the NIR spectra were used to provide fingerprints thereby avoiding the need to develop predictive regression models for specific constituents of particulate matter (cf. Collins et al., 2013).

3.4.3. Apportioning the sources of the sediment-bound organic matter infiltrating artificial salmonid redds using numerical mass balance modelling

The relative contributions of the four sources to the interstitial sediment-bound organic matter were estimated using the mass balance mixing model reported by Collins et al. (2013). The objective function used by this numerical model optimises a set of linear equations for each composite signature by minimising the sum of squares of the weighted relative errors, viz.:

$\sum_{i=1}^{n}\left\{\frac{C_{i}-\left(\sum_{s=1}^{m} P_{s} S_{s i} \mathrm{SV} s i\right)}{C_{i}}\right\}^{2} W_{i}$

where: $C_{i}=$ deviate median concentration of fingerprint property (i) in the interstitial sediment samples collected during each period of deploying retrievable basket traps; $P_{s}=$ the optimised percentage contribution from source category $(s) ; S_{s i}=$ deviate median concentration of fingerprint property $(i)$ in source category $(s)$; $\mathrm{SV}_{s i}=$ weighting representing the within-source variation of fingerprint property $(i)$ in source category $(s) ; W_{\mathrm{i}}=$ tracer discriminatory weighting; $n=$ number of fingerprint properties comprising the optimum composite fingerprint; $m=$ number of interstitial sediment-bound organic matter source categories.

Table 4

Optimum composite fingerprints selected using the KW- $H$ test for discriminating the sources of the interstitial sediment-bound organic matter.

\begin{tabular}{|c|c|c|}
\hline Property & $(\%)^{a}$ & $\mathrm{TDW}^{\mathrm{b}}$ \\
\hline \multicolumn{3}{|l|}{ ITHON } \\
\hline$\delta^{15} \mathrm{~N}$ & 68 & 1.00 \\
\hline Aromatic & 75 & 1.11 \\
\hline $\mathrm{CH}_{2}$ & 80 & 1.19 \\
\hline $\mathrm{CH}_{3}$ & 78 & 1.15 \\
\hline $\mathrm{HC}=\mathrm{CH}$ & 75 & 1.11 \\
\hline Total $^{\mathrm{c}}$ & 98 & \\
\hline \multicolumn{3}{|l|}{ LUGG } \\
\hline$\delta^{13} \mathrm{C}$ & 73 & 1.12 \\
\hline$\delta^{15} \mathrm{~N}$ & 80 & 1.23 \\
\hline $\mathrm{HC}=\mathrm{CH}$ & 70 & 1.08 \\
\hline $\mathrm{CH}_{3}$ & 70 & 1.08 \\
\hline $\mathrm{ArNH}_{2}$ & 65 & 1.00 \\
\hline Total $^{\mathrm{C}}$ & 95 & \\
\hline \multicolumn{3}{|l|}{ REDE } \\
\hline$\delta^{15} \mathrm{~N}$ & 83 & 1.10 \\
\hline Cellulose & 75 & 1.00 \\
\hline $\mathrm{CH}_{2}$ & 75 & 1.00 \\
\hline $\mathrm{CONH}_{2}$ & 75 & 1.00 \\
\hline $\mathrm{CH}_{3}$ & 75 & 1.00 \\
\hline Total $^{\mathrm{C}}$ & 98 & \\
\hline
\end{tabular}

The mass balance mixing model boundary constraints for the relative contributions from each of the potential sources were set to $0><1$. Within-source variation weightings were calculated using the inverse of the coefficient of variation measured for each fingerprint property in any composite signature. Where necessary, these weightings can be scaled between 0 and 1 by dividing by the maximum source weight for each property in the composite

Table 5

Ranked fingerprint property loadings generated using PCA.

\begin{tabular}{|c|c|c|c|c|c|}
\hline Property & Overtone & $\mathrm{PC}-1^{\mathrm{a}}$ & Property & Overtone & $\mathrm{PC}-2^{\mathrm{b}}$ \\
\hline \multicolumn{6}{|l|}{ ITHON } \\
\hline$\delta^{15} \mathrm{~N}$ & - & 1.000 & $\mathrm{CH}_{3}$ & 3 & 0.266 \\
\hline $\mathrm{CH}_{2}$ & 2 & 0.006 & $\mathrm{CH}$ & 3 & 0.247 \\
\hline $\mathrm{CH}_{3}$ & 2 & 0.005 & $\mathrm{CH}_{2}$ & 3 & 0.246 \\
\hline $\mathrm{CH}_{3}$ & 3 & 0.004 & Aromatic & 3 & 0.242 \\
\hline Starch & 2 & 0.004 & $\mathrm{CH}_{2}$ & 2 & 0.241 \\
\hline Aromatic & 2 & 0.004 & $\mathrm{HC}=\mathrm{CH}$ & 3 & 0.237 \\
\hline $\mathrm{ROH}$ & 2 & 0.003 & Aromatic & 2 & 0.233 \\
\hline Starch, glucose & 2 & 0.003 & $\mathrm{RNH}_{2}$ & 3 & 0.230 \\
\hline $\mathrm{C}=\mathrm{H}$ & 2 & 0.003 & $\mathrm{ROH}$ & 2 & 0.229 \\
\hline $\mathrm{RNH}_{2}$ & 2 & 0.003 & $\mathrm{CH}_{3}$ & 2 & 0.226 \\
\hline $\mathrm{CH}$ & 2 & 0.003 & $\mathrm{ArOH}$ & 2 & 0.224 \\
\hline $\mathrm{CH}_{2}$ & 3 & 0.003 & $\mathrm{ArNH}_{2}$ & 3 & 0.222 \\
\hline $\mathrm{ArOH}$ & 2 & 0.002 & Starch & 2 & 0.221 \\
\hline $\mathrm{ArNH}_{2}$ & 3 & 0.002 & Starch, glucose & 2 & 0.220 \\
\hline $\mathrm{RNH}_{2}$ & 3 & 0.001 & Protein & 3 & 0.218 \\
\hline $\mathrm{CH}$ & 3 & 0.001 & $\mathrm{C}=\mathrm{H}$ & 2 & 0.213 \\
\hline Protein & 3 & 0.001 & $\mathrm{ArOH}$ & 3 & 0.212 \\
\hline $\mathrm{ArOH}$ & 3 & 0.001 & $\mathrm{RNH}_{2}$ & 2 & 0.212 \\
\hline Aromatic & 3 & 0.001 & $\mathrm{CH}$ & 2 & 0.211 \\
\hline $\mathrm{HC}=\mathrm{CH}$ & 3 & 0.000 & $\delta^{15} \mathrm{~N}$ & - & 0.012 \\
\hline VE\% & & 99.2 & VE\% & & 0.8 \\
\hline \multicolumn{6}{|l|}{ LUGG } \\
\hline$\delta^{15} \mathrm{~N}$ & - & 0.949 & $\delta^{13} \mathrm{~N}$ & - & 0.949 \\
\hline$\delta^{13} \mathrm{~N}$ & - & 0.316 & $\delta^{15} \mathrm{~N}$ & - & 0.315 \\
\hline $\mathrm{CH}_{3}$ & 3 & 0.002 & $\mathrm{HC}=\mathrm{CH}$ & 3 & 0.008 \\
\hline $\mathrm{HC}=\mathrm{CH}$ & 3 & 0.001 & Aromatic & 3 & 0.008 \\
\hline $\mathrm{CH}_{2}$ & 3 & 0.001 & $\mathrm{CH}$ & 3 & 0.007 \\
\hline $\mathrm{ArNH}_{2}$ & 3 & 0.001 & Protein & 3 & 0.006 \\
\hline Aromatic & 3 & 0.001 & $\mathrm{CH}_{2}$ & 3 & 0.006 \\
\hline Protein & 3 & 0.000 & $\mathrm{ArNH}_{2}$ & 3 & 0.006 \\
\hline $\mathrm{CH}$ & 3 & 0.000 & $\mathrm{RNH}_{2}$ & 3 & 0.006 \\
\hline $\mathrm{RNH}_{2}$ & 3 & 0.000 & $\mathrm{CH}_{3}$ & 3 & 0.005 \\
\hline VE\% & & 87.7 & VE\% & & 12.1 \\
\hline \multicolumn{6}{|l|}{ REDE } \\
\hline$\delta^{15} \mathrm{~N}$ & - & 1.000 & $\mathrm{CH}_{3}$ & 3 & 0.222 \\
\hline $\mathrm{HC}=\mathrm{CH}$ & 3 & 0.008 & $\mathrm{CH}$ & 3 & 0.217 \\
\hline Aromatic & 3 & 0.008 & $\mathrm{CH}_{2}$ & 2 & 0.215 \\
\hline $\mathrm{ArOH}$ & 3 & 0.007 & $\mathrm{CH}_{2}$ & 3 & 0.212 \\
\hline $\mathrm{CH}$ & 3 & 0.007 & Aromatic & 3 & 0.211 \\
\hline Protein & 3 & 0.007 & $\mathrm{CH}_{3}$ & 2 & 0.211 \\
\hline $\mathrm{RNH}_{2}$ & 3 & 0.007 & $\mathrm{HC}=\mathrm{CH}$ & 3 & 0.210 \\
\hline $\mathrm{ArOH}$ & 2 & 0.007 & Aromatic & 2 & 0.208 \\
\hline $\mathrm{ArNH}_{2}$ & 3 & 0.007 & $\mathrm{ROH}$ & 2 & 0.207 \\
\hline $\mathrm{CH}$ & 2 & 0.006 & Starch, glucose & 2 & 0.206 \\
\hline $\mathrm{RNH}_{2}$ & 2 & 0.006 & Starch & 2 & 0.204 \\
\hline $\mathrm{C}=\mathrm{H}$ & 2 & 0.006 & Cellulose & 2 & 0.204 \\
\hline $\mathrm{CH}_{2}$ & 3 & 0.006 & $\mathrm{ArOH}$ & 2 & 0.203 \\
\hline Starch, glucose & 2 & 0.006 & $\mathrm{C}=\mathrm{H}$ & 2 & 0.201 \\
\hline CONHR & 2 & 0.006 & $\mathrm{RNH}_{2}$ & 3 & 0.201 \\
\hline $\mathrm{ArNH}_{2}$ & 2 & 0.006 & $\mathrm{RNH}_{2}$ & 2 & 0.200 \\
\hline $\mathrm{ROH}$ & 2 & 0.005 & Protein & 2 & 0.199 \\
\hline Protein & 2 & 0.005 & $\mathrm{CONH}_{2}$ & 2 & 0.198 \\
\hline Aromatic & 2 & 0.005 & $\mathrm{ArNH}_{2}$ & 3 & 0.196 \\
\hline Starch & 2 & 0.005 & $\mathrm{CH}$ & 2 & 0.195 \\
\hline $\mathrm{CONH}_{2}$ & 2 & 0.005 & $\mathrm{ArNH}_{2}$ & 2 & 0.195 \\
\hline $\mathrm{CH}_{3}$ & 2 & 0.004 & Protein & 3 & 0.194 \\
\hline $\mathrm{CH}_{3}$ & 3 & 0.004 & CONHR & 2 & 0.194 \\
\hline Cellulose & 2 & 0.004 & $\mathrm{ArOH}$ & 3 & 0.189 \\
\hline $\mathrm{CH}_{2}$ & 2 & 0.003 & $\delta^{15} \mathrm{~N}$ & - & 0.028 \\
\hline VE\% & & 98.5 & VE\% & & 1.5 \\
\hline
\end{tabular}

a Principal component 1.

b Principal component 2; VE\% variance explained. 
Table 6

Optimum composite fingerprints selected using PCA for discriminating the sources of interstitial sediment-bound organic matter.

\begin{tabular}{|c|c|c|}
\hline Property & $(\%)^{a}$ & $\mathrm{TDW}^{\mathrm{b}}$ \\
\hline \multicolumn{3}{|l|}{ ITHON } \\
\hline$\delta^{15} \mathrm{~N}$ & 68 & 1.00 \\
\hline $\mathrm{CH}$ & 68 & 1.00 \\
\hline $\mathrm{CH}_{2}$ & 73 & 1.07 \\
\hline $\mathrm{CH}_{3}$ & 78 & 1.15 \\
\hline Aromatic & 80 & 1.19 \\
\hline Total $^{\mathrm{c}}$ & 98 & \\
\hline \multicolumn{3}{|l|}{ LUGG } \\
\hline$\delta^{13} \mathrm{~N}$ & 80 & 1.33 \\
\hline$\delta^{15} \mathrm{~N}$ & 73 & 1.21 \\
\hline $\mathrm{CH}_{3}$ & 70 & 1.17 \\
\hline $\mathrm{HC}=\mathrm{CH}$ & 70 & 1.17 \\
\hline Aromatic & 60 & 1.00 \\
\hline Total $^{\mathrm{C}}$ & 95 & \\
\hline \multicolumn{3}{|l|}{ REDE } \\
\hline$\delta^{15} \mathrm{~N}$ & 83 & 1.14 \\
\hline $\mathrm{CH}_{2}$ & 75 & 1.03 \\
\hline $\mathrm{CH}$ & 75 & 1.03 \\
\hline $\mathrm{CH}_{3}$ & 73 & 1.00 \\
\hline $\mathrm{HC}=\mathrm{CH}$ & 75 & 1.03 \\
\hline Total $^{\mathrm{c}}$ & 100 & \\
\hline
\end{tabular}

a \% Source samples classified correctly by individual properties.

b Tracer discriminatory weighting used in the mass balance numerical modelling.

c \% Source samples classified correctly by composite signature.

fingerprint. Discriminatory power weightings were based on the relative discriminatory efficiency of each individual fingerprint property comprising any specific composite signature identified using the statistical tests (see Tables 4, 6 and 7). On this basis, the discriminatory power of the property providing the lowest discrimination (\%) of the sediment-bound organic matter source samples was assigned a value of 1.0 and the corresponding preliminary weightings for the remainder of the properties were calculated using the ratio of their discriminatory efficiency to that of the weakest property in any specific composite signature. For data sets where the range of discriminatory weightings for any specific signature is significant, it is advisable that these preliminary values are divided by the maximum for the composite fingerprint to ensure that the final weightings all scale between 0 and 1 .

Fingerprint property distributions were generated using the median as a robust estimator of location and the scaler $Q_{\mathrm{n}}$ (Collins et al., 2012b) to provide input values to the mass balance mixing model. Distributions were generated for both the source and interstitial sediment samples collected from each study catchment. A Monte Carlo routine based on latin hypercube sampling, as opposed to random sampling, was used to generate repeat mixing model iterations (5000 for each composite fingerprint). The repeat iterations generated feasible predicted median relative contributions from each catchment source which were used to construct output distributions or probability density functions (pdfs). Calculation of $95 \%$ confidence limits about the average median inputs, using 10 sets of 5000 repeat iterations for each period of deploying the retrievable basket samplers, provided a basis for assessing the convergence of the average model solutions. The full uncertainty ranges in the predicted median relative contributions from each source were recorded, as opposed to the confidence intervals which can be derived from the 2.5 and 97.5 percentiles of each pdf. Relative frequency-weighted average median source proportions were calculated using the output pdfs (cf. Collins et al.,
Table 7

Optimum composite fingerprints selected using GA-DFA for discriminating the sources of the interstitial sediment-bound organic matter.

\begin{tabular}{|c|c|c|c|c|c|c|c|c|}
\hline \multicolumn{3}{|l|}{ GA-DFA 1} & \multicolumn{3}{|l|}{ GA-DFA 2} & \multicolumn{3}{|l|}{ GA-DFA 3} \\
\hline Property & $(\%)$ & $\mathrm{TDW}^{\mathrm{b}}$ & Property & $\begin{array}{l}(\%) \\
\mathrm{a}\end{array}$ & $\mathrm{TDW}^{\mathrm{b}}$ & Property & $\begin{array}{l}(\%) \\
a\end{array}$ & $\overline{\text { TDW }^{\mathrm{b}}}$ \\
\hline \multicolumn{9}{|l|}{ ITHON } \\
\hline $\mathrm{CH}$ & 73 & 1.04 & $\mathrm{C}=\mathrm{H}$ & 70 & 1.00 & $\mathrm{CH}$ & 73 & 1.04 \\
\hline $\mathrm{CH}_{2}$ & 80 & 1.14 & $\mathrm{CH}$ & 73 & 1.04 & $\mathrm{CH}_{2}$ & 80 & 1.14 \\
\hline $\mathrm{RNH}_{2}$ & 70 & 1.00 & $\mathrm{CH}_{2}$ & 80 & 1.14 & $\mathrm{ROH}$ & 78 & 1.11 \\
\hline $\mathrm{ROH}$ & 78 & 1.11 & $\mathrm{ROH}$ & 78 & 1.11 & $\mathrm{ArOH}$ & 70 & 1.00 \\
\hline $\mathrm{HC}=\mathrm{CH}$ & 75 & 1.07 & $\begin{array}{l}\text { Starch, } \\
\text { glucose }\end{array}$ & 70 & 1.00 & $\mathrm{CH}_{3}$ & 78 & 1.11 \\
\hline Total $^{\mathrm{c}}$ & 100 & & Total $^{\mathrm{C}}$ & 100 & & Total $^{\mathrm{c}}$ & 100 & \\
\hline \multicolumn{9}{|l|}{ LUGG } \\
\hline$\delta^{15} \mathrm{~N}$ & 80 & 1.39 & $\delta^{13} \mathrm{~N}$ & 73 & 1.12 & $\delta^{15} \mathrm{~N}$ & 80 & 1.23 \\
\hline $\mathrm{ArNH}_{2}$ & 65 & 1.13 & $\delta^{15} \mathrm{~N}$ & 80 & 1.23 & $\mathrm{ArNH}_{2}$ & 65 & 1.00 \\
\hline $\mathrm{CH}_{2}$ & 65 & 1.13 & $\mathrm{CH}$ & 65 & 1.00 & $\mathrm{CH}_{3}$ & 70 & 1.08 \\
\hline Protein & 58 & 1.00 & $\mathrm{HC}=\mathrm{CH}$ & 70 & 1.08 & $\mathrm{HC}=\mathrm{CH}$ & 70 & 1.08 \\
\hline $\mathrm{RNH}_{2}$ & 65 & 1.13 & $\mathrm{RNH}_{2}$ & 65 & 1.00 & $\mathrm{RNH}_{2}$ & 65 & 1.00 \\
\hline Total $^{\mathrm{C}}$ & 95 & & Total $^{\mathrm{C}}$ & 95 & & Total $^{\mathrm{C}}$ & 95 & \\
\hline \multicolumn{9}{|l|}{ REDE } \\
\hline$\delta^{15} \mathrm{~N}$ & 83 & 1.22 & $\delta^{15} \mathrm{~N}$ & 83 & 1.32 & $\delta^{15} \mathrm{~N}$ & 83 & 1.14 \\
\hline Aromatic & 78 & 1.15 & Cellulose & 75 & 1.20 & $\mathrm{ArOH}$ & 78 & 1.07 \\
\hline $\mathrm{CH}_{2}$ & 75 & 1.11 & Starch & 75 & 1.20 & $\mathrm{CH}_{3}$ & 75 & 1.03 \\
\hline $\mathrm{ArOH}$ & 68 & 1.00 & $\mathrm{HC}=\mathrm{CH}$ & 75 & 1.20 & $\mathrm{CONH}_{2}$ & 75 & 1.03 \\
\hline $\mathrm{HC}=\mathrm{CH}$ & 75 & 1.11 & Protein & 63 & 1.00 & $\mathrm{ArNH}_{2}$ & 73 & 1.00 \\
\hline Total 3 & 100 & & Total 3 & 100 & & Total 3 & 100 & \\
\hline
\end{tabular}

2012b). Relative frequency-weighted average median source proportions generated using the five signatures for each basket extraction campaign were accepted on the basis of the goodnessof-fit (GOF) threshold of 0.85 (cf. Walling and Collins, 2000). Calculation of the GOF was based on the relative error between measured median fingerprint property values for the fine-grained interstitial samples collected from the artificial salmonid redds and

Table 8

The GOF using each optimum composite fingerprint in the numerical mass balance model to predict the median fingerprint values measured for the interstitial sediment samples collected from each set of sampling baskets.

\begin{tabular}{|c|c|c|c|c|}
\hline Basket extraction & Signature & $\begin{array}{l}\text { ITHON } \\
\text { GOF }\end{array}$ & $\begin{array}{l}\text { LUGG } \\
\text { GOF }\end{array}$ & $\begin{array}{l}\text { REDE } \\
\text { GOF }\end{array}$ \\
\hline \multirow{5}{*}{$\begin{array}{l}\text { February } 2011 \\
\text { (Eyeing stage) }\end{array}$} & $\mathrm{KW}-\mathrm{H}$ & 0.995 & 0.993 & 0.995 \\
\hline & PCA & 0.996 & 0.993 & 0.994 \\
\hline & GA-DFA 1 & 0.995 & 0.992 & 0.993 \\
\hline & GA-DFA 2 & 0.995 & 0.993 & 0.994 \\
\hline & GA-DFA 3 & 0.996 & 0.992 & 0.994 \\
\hline \multirow{5}{*}{$\begin{array}{l}\text { March } 2011 \\
\text { (Hatch stage) }\end{array}$} & $\mathrm{KW}-\mathrm{H}$ & 0.995 & 0.992 & 0.993 \\
\hline & PCA & 0.994 & 0.991 & 0.995 \\
\hline & GA-DFA 1 & 0.995 & 0.990 & 0.994 \\
\hline & GA-DFA 2 & 0.995 & 0.992 & 0.994 \\
\hline & GA-DFA 3 & 0.994 & 0.990 & 0.994 \\
\hline \multirow{5}{*}{$\begin{array}{l}\text { April } 2011 \\
\text { (Emergence stage) }\end{array}$} & $\mathrm{KW}-\mathrm{H}$ & 0.993 & 0.992 & 0.994 \\
\hline & PCA & 0.994 & 0.991 & 0.995 \\
\hline & GA-DFA 1 & 0.994 & 0.992 & 0.995 \\
\hline & GA-DFA 2 & 0.995 & 0.991 & 0.995 \\
\hline & GA-DFA 3 & 0.995 & 0.992 & 0.995 \\
\hline \multirow{5}{*}{$\begin{array}{l}\text { May } 2011 \\
\text { (Late spawning stage) }\end{array}$} & KW-H & 0.995 & 0.994 & 0.994 \\
\hline & PCA & 0.995 & 0.993 & 0.995 \\
\hline & GA-DFA 1 & 0.995 & 0.993 & 0.995 \\
\hline & GA-DFA 2 & 0.994 & 0.994 & 0.994 \\
\hline & GA-DFA 3 & 0.995 & 0.993 & 0.995 \\
\hline
\end{tabular}




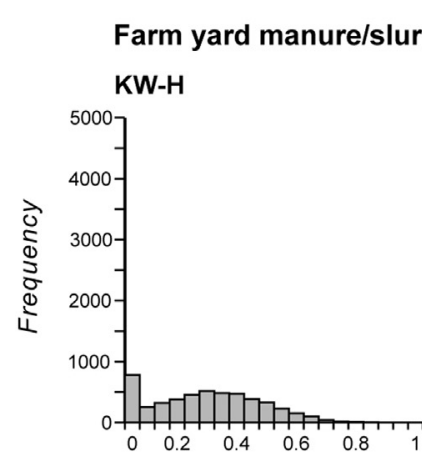
In-stream
Vegetation
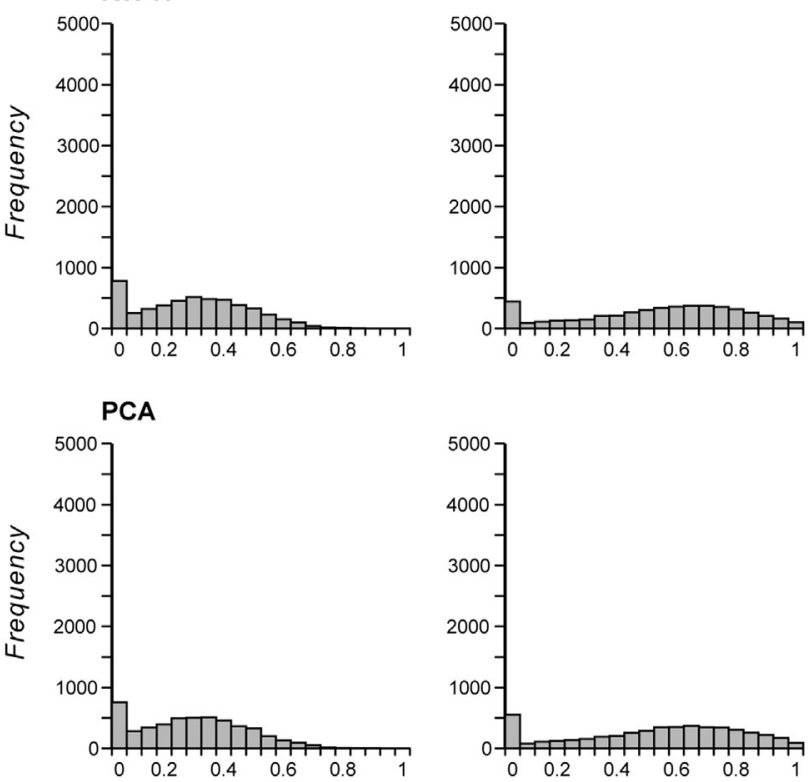

GA-DFA 1

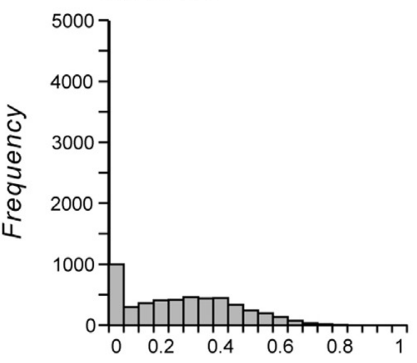

GA-DFA 2

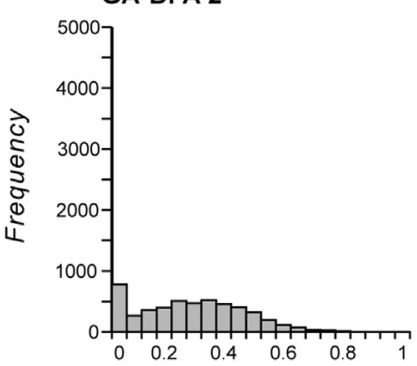

GA-DFA 3
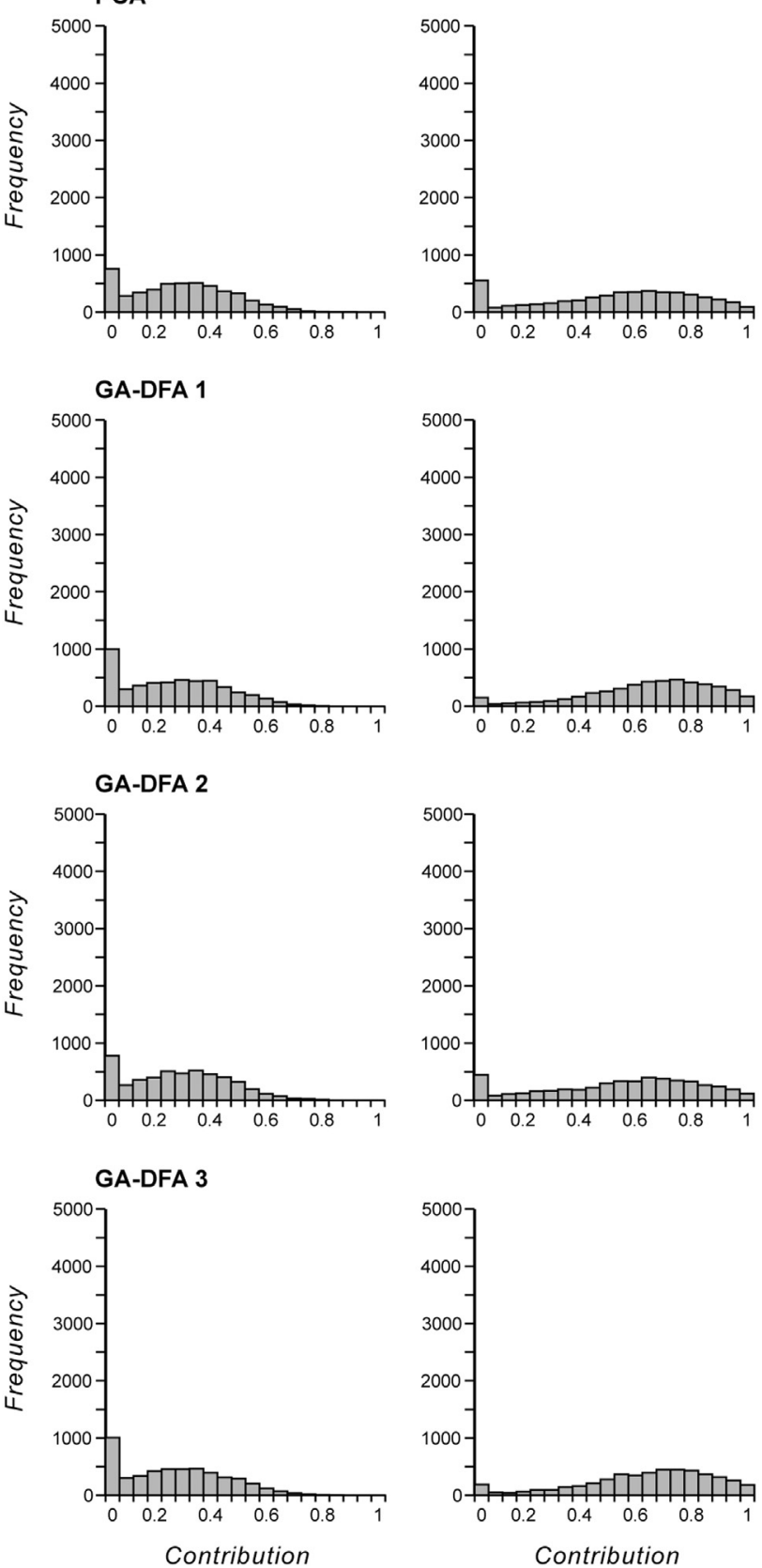
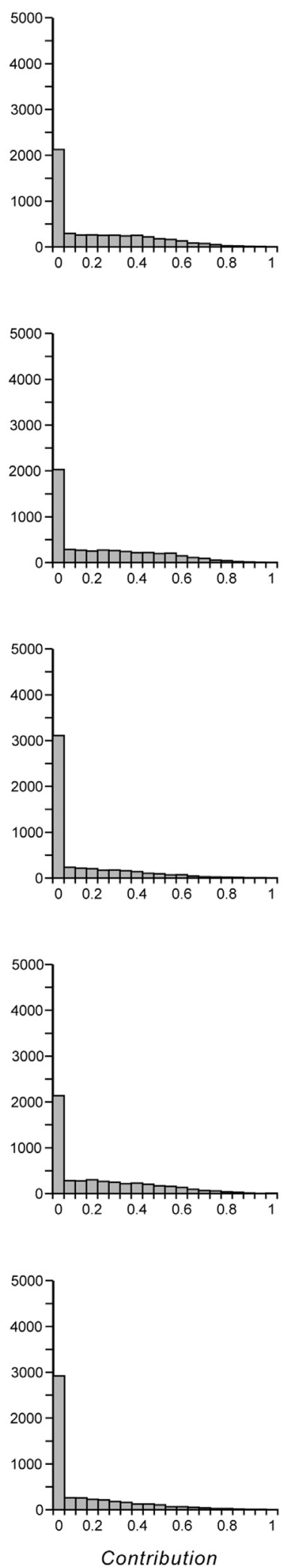
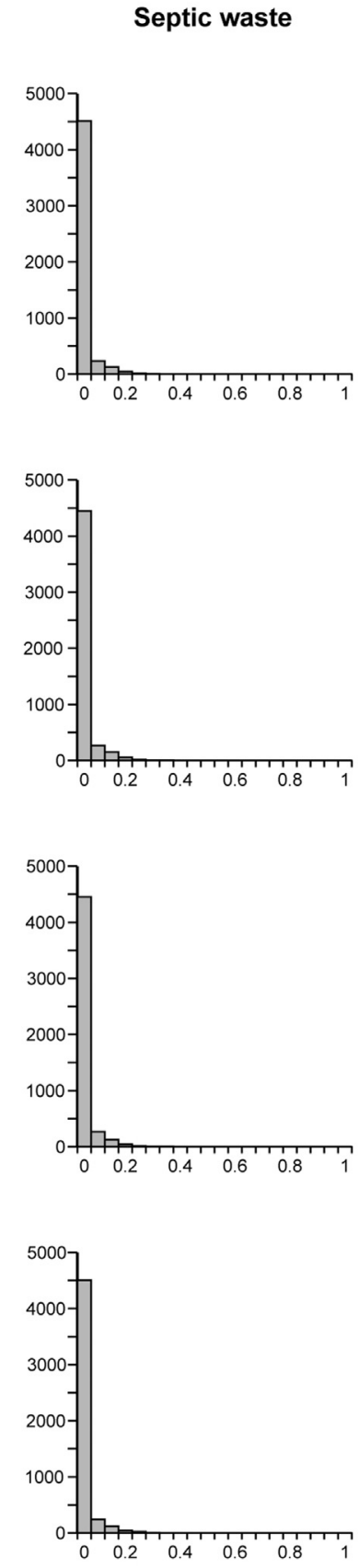

Septic waste

Damaged

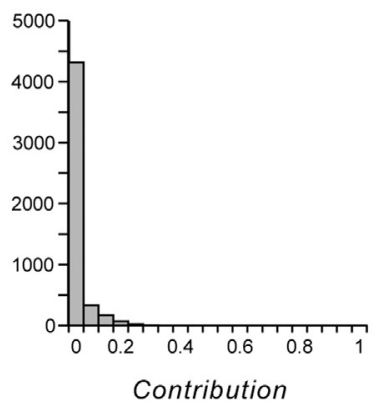

Fig. 3. Mass balance model output pdfs for the eyeing stage interstitial baskets deployed between December 2010 and February 2011 on the River Lugg.

those predicted using the feasible median source proportions in combination with the corresponding measured source property values. Only the predicted source proportions provided by composite signatures yielding a GOF $\geq 0.85$ were accepted. The GOF estimates were multiplied by the corresponding discriminatory efficiencies of these signatures in an additional weighting 


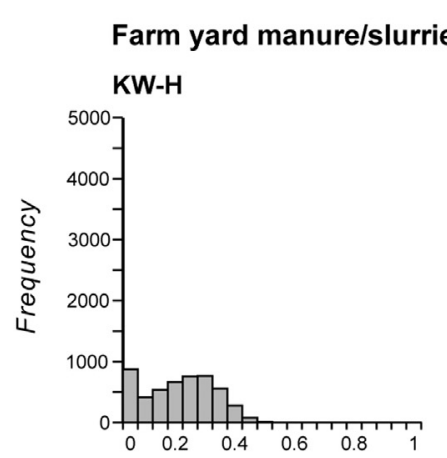

In-stream

Damaged road verges

Septic waste
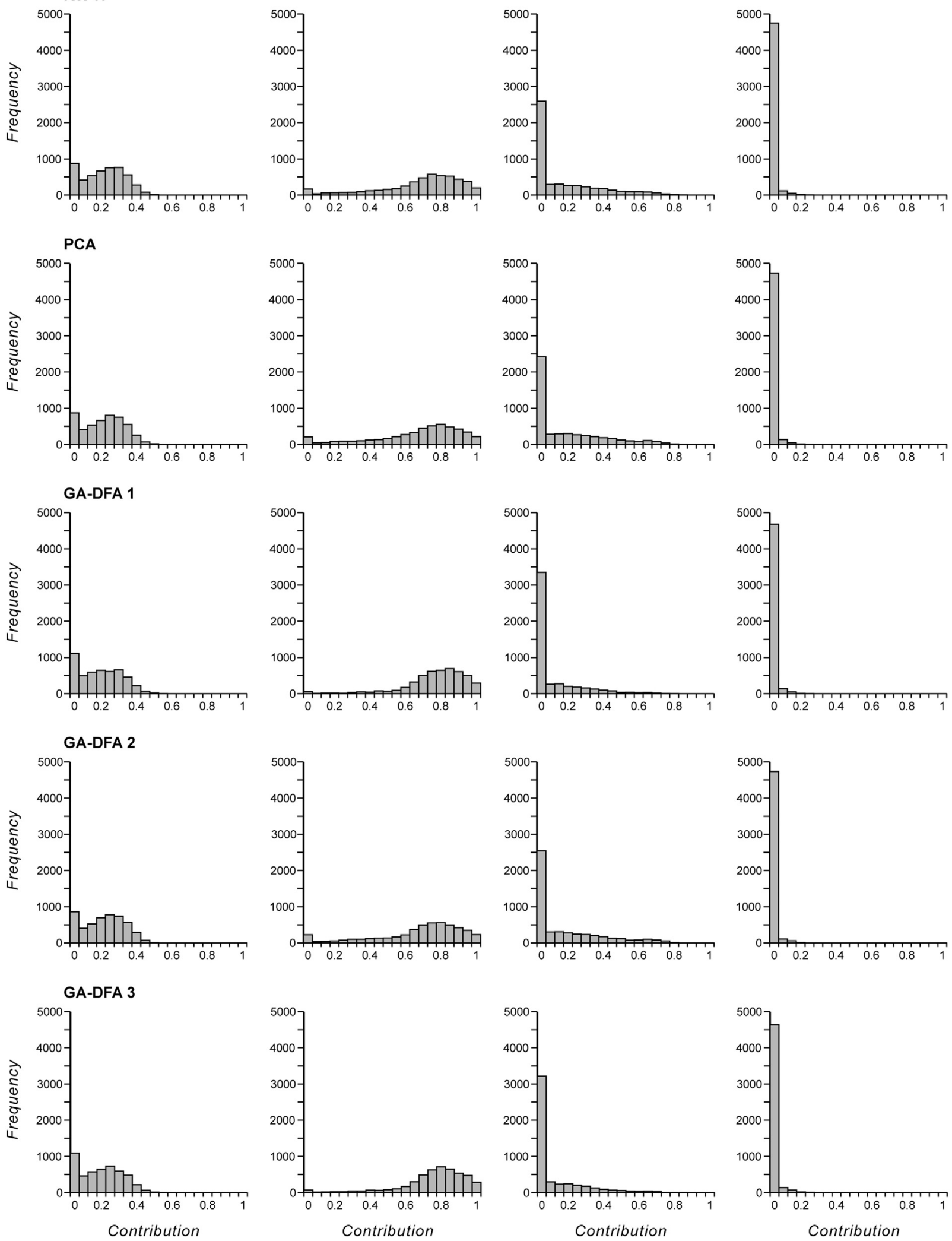

Fig. 4. Mass balance model output pdfs for the hatching stage interstitial baskets deployed between December 2010 and March 2011 on the River Lugg.

procedure to estimate the final relative frequency-weighted average median source contributions. This procedure ensured that the final source estimates take explicit account of the prediction of the measured median property values in the interstitial sediment samples, plus the discriminatory power provided by the corresponding signature. Use of the latter 


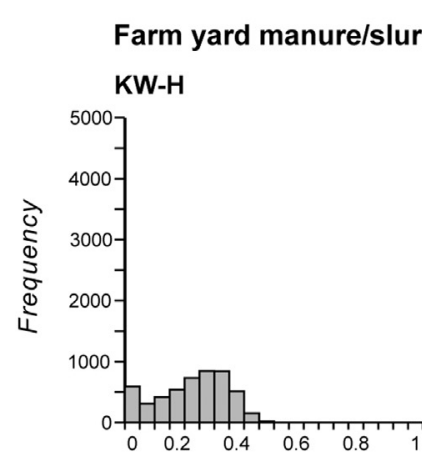
In-stream
Vegetation

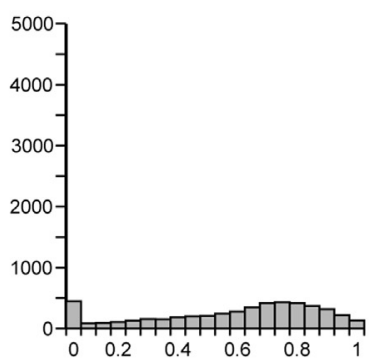

PCA

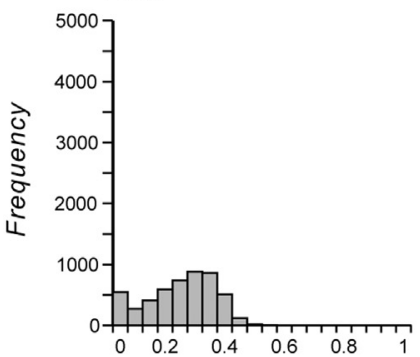

GA-DFA 1

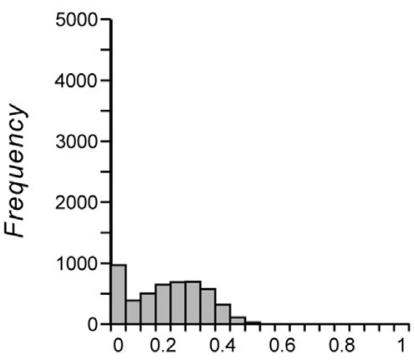

GA-DFA 2

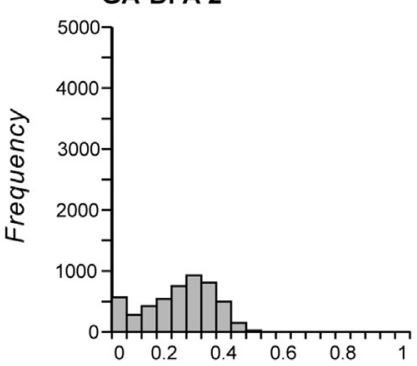

GA-DFA 3
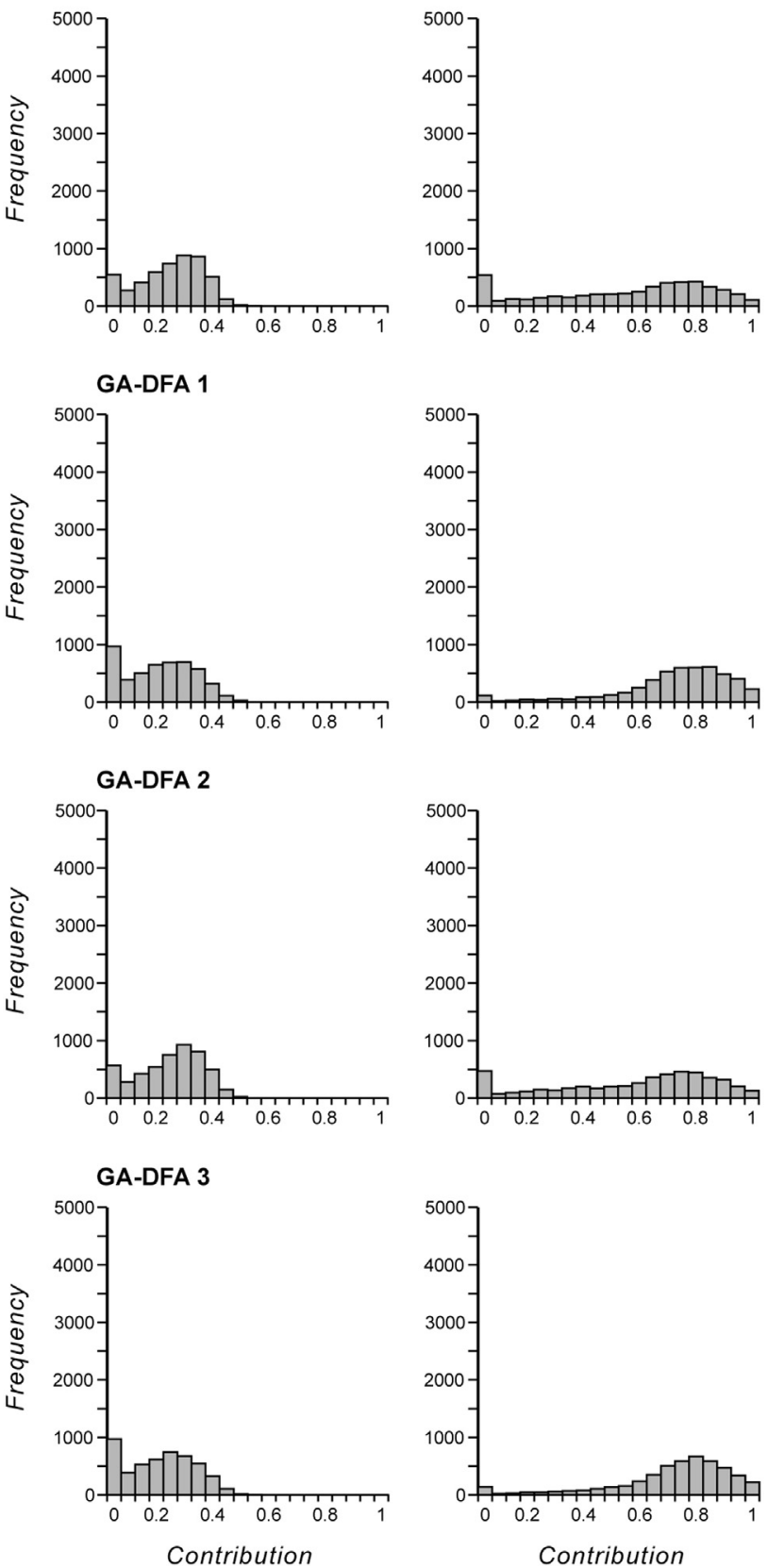

Damaged road verges
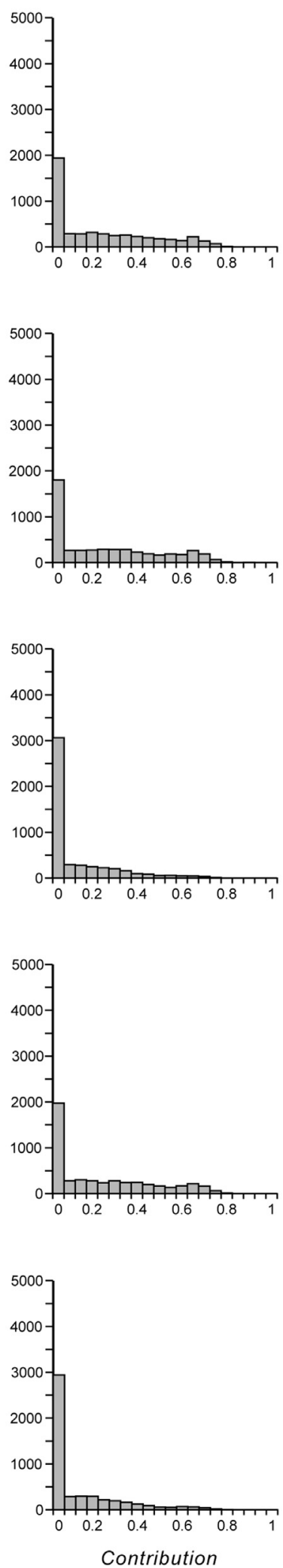
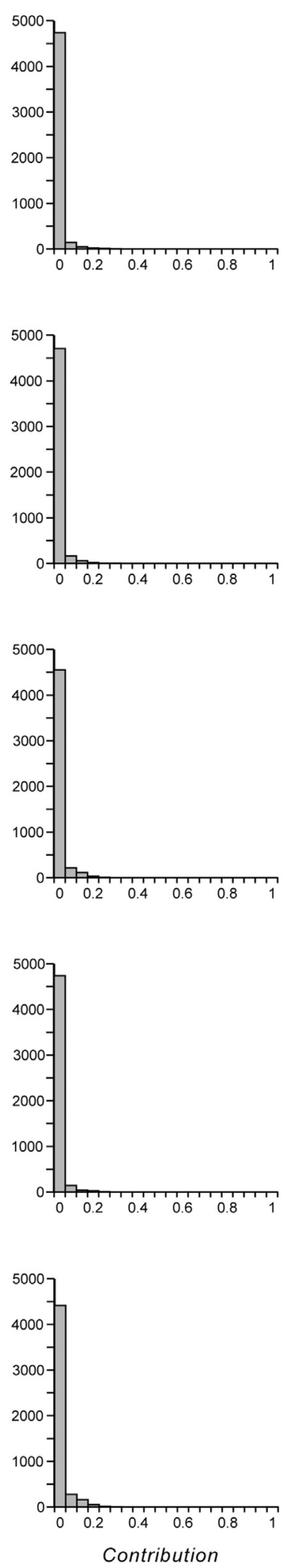

Fig. 5. Mass balance model output pdfs for the emergence stage interstitial baskets deployed between December 2010 and April 2011 on the River Lugg.

information provides a direct link between statistical discrimination of the sources and the subsequent allocation of source proportions using the mass balance model. This final weighting procedure is more meaningful than simply selecting predicted source proportions generated using different signatures on the basis of a GOF threshold and averaging them (cf. Collins et al., 


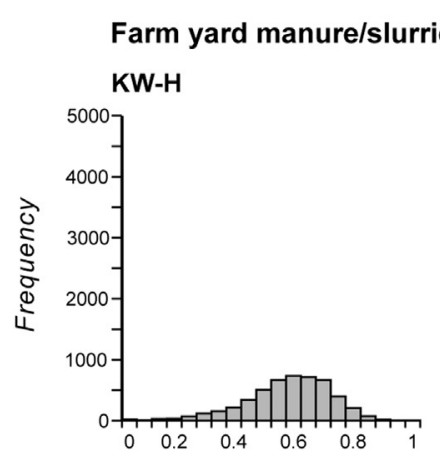

In-stream

Damaged road verges

Septic waste
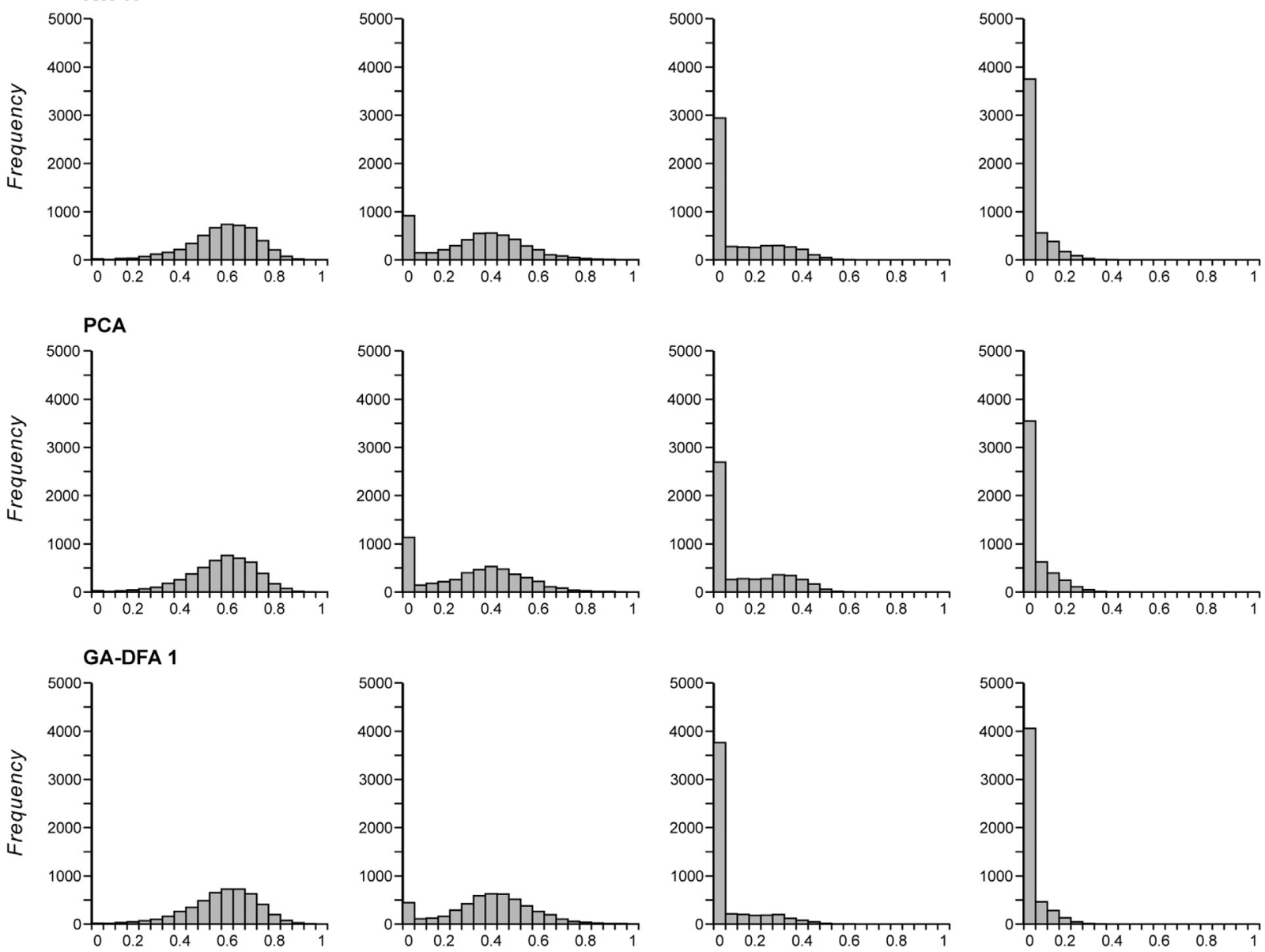

GA-DFA 2
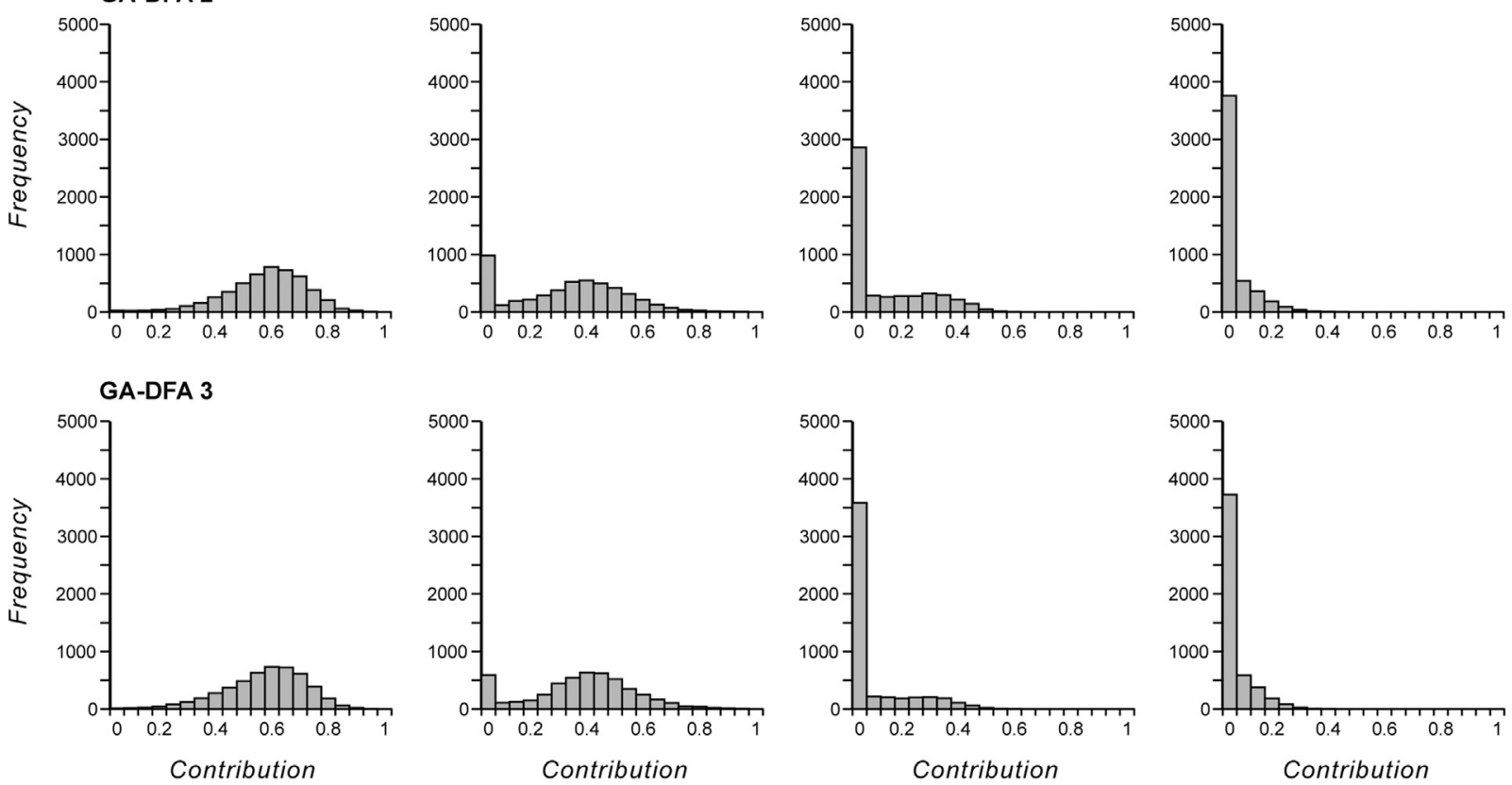

Fig. 6. Mass balance model output pdfs for the late spawning stage interstitial baskets deployed between December 2010 and May 2011 on the River Lugg.

2013), since the discriminatory power of optimum composite signatures yielding the same GOF can frequently differ. Both local and global (genetic algorithm; GA) optimisation were used during the Monte Carlo analysis (Collins et al., 2010b, 2012b). GA-driven optimisation was initiated with the output from the local (non-GA) search tool as the starting point. The outputs from the local and 
global solution modelling were compared using the minimisation of the objective function and the corresponding GOF (cf. Collins et al., 2010b).

\section{Results and discussion}

GA optimisation did not generate improved GOF with the tracer values measured for the interstitial sediment samples recovered from the artificial redds. On this basis, the outputs of the local optimisation version of the mixing model were selected and the corresponding GOF estimates for each composite signature for each basket extraction are presented in Table 8. These values are well above the threshold of 0.85 which has been widely used in source fingerprinting studies. Comparison of local and GA optimisation is an essential part of source tracing studies using mass balance mixing models (cf. Collins et al., 2010c, 2013). Analysis of the convergence of the average median source proportions using 10 repeat sets of Monte Carlo analysis for each basket extraction in each of the River Ithon, Lugg and Rede catchments yielded 95\% confidence limits well within the range $\pm 1 \%$. Example output pdfs showing the full uncertainty ranges in the mixing model predictions for the River Lugg channel sampling site are presented in Figs. 3-6.

The final estimates for median farm yard manure/slurry contributions to the interstitial sediment-associated organic matter collected from the River Ithon sampling site ranged between $36 \%$ (full uncertainty range $0-100 \%$ ) at the hatching stage to $48 \%$ (full uncertainty range $0-100 \%$ ) at late spawning (Table 9). Tables 10 and 11, respectively, show broadly similar patterns for the Rivers Lugg and Rede, with the corresponding

Table 9

Summary of the predicted median source proportions (\%) for the River Ithon study catchment (single values represent relative frequency-weighted average medians; ranges represent the full uncertainty in the median contributions predicted by the Monte Carlo repeat runs of the mass balance model).

\begin{tabular}{|c|c|c|c|c|c|}
\hline Basket extraction & Signature & $\begin{array}{l}\text { Farm } \\
\text { yard } \\
\text { manure/ } \\
\text { slurries }\end{array}$ & $\begin{array}{l}\text { Damaged } \\
\text { road } \\
\text { verges }\end{array}$ & $\begin{array}{l}\text { Instream } \\
\text { decaying } \\
\text { vegetation }\end{array}$ & Human septic waste \\
\hline \multirow{11}{*}{$\begin{array}{l}\text { February } 2011 \\
\text { (Eyeing stage) }\end{array}$} & \multirow[t]{2}{*}{ KW-H } & 34 & 14 & 47 & 4 \\
\hline & & $0-97$ & $0-79$ & $0-100$ & $0-29$ \\
\hline & \multirow[t]{2}{*}{ PCA } & 33 & 16 & 47 & 4 \\
\hline & & $0-97$ & $0-80$ & $0-100$ & $0-26$ \\
\hline & \multirow[t]{2}{*}{ GA-DFA 1} & 51 & 10 & 34 & 5 \\
\hline & & $0-100$ & $0-77$ & $0-100$ & $0-34$ \\
\hline & \multirow[t]{2}{*}{ GA-DFA 2} & 58 & 9 & 29 & 5 \\
\hline & & $0-100$ & $0-68$ & $0-100$ & $0-34$ \\
\hline & \multirow[t]{2}{*}{ GA-DFA 3} & 49 & 10 & 36 & 5 \\
\hline & & $0-100$ & $0-70$ & $0-100$ & $0-36$ \\
\hline & Weighted average ${ }^{a}$ & 45 & 12 & 39 & 4 \\
\hline \multirow{11}{*}{$\begin{array}{l}\text { March } 2011 \\
\text { (Hatch stage) }\end{array}$} & \multirow[t]{2}{*}{$\mathrm{KW}-\mathrm{H}$} & 34 & 14 & 48 & 4 \\
\hline & & $0-97$ & $0-72$ & $0-100$ & $0-23$ \\
\hline & \multirow[t]{2}{*}{ PCA } & 36 & 11 & 50 & 3 \\
\hline & & $0-99$ & $0-77$ & $0-100$ & $0-27$ \\
\hline & \multirow[t]{2}{*}{ GA-DFA 1} & 36 & 12 & 49 & 3 \\
\hline & & $0-99$ & $0-86$ & $0-100$ & $0-22$ \\
\hline & \multirow[t]{2}{*}{ GA-DFA 2} & 36 & 12 & 49 & 3 \\
\hline & & $0-99$ & $0-75$ & $0-100$ & $0-23$ \\
\hline & \multirow[t]{2}{*}{ GA-DFA 3} & 36 & 11 & 50 & 3 \\
\hline & & $0-100$ & $0-80$ & $0-100$ & $0-23$ \\
\hline & Weighted average $^{a}$ & 36 & 12 & 49 & 3 \\
\hline \multirow{11}{*}{$\begin{array}{l}\text { April } 2011 \\
\quad \text { (Emergence stage) }\end{array}$} & \multirow[t]{2}{*}{ KW-H } & 33 & 12 & 52 & 3 \\
\hline & & $0-99$ & $0-85$ & $0-100$ & $0-26$ \\
\hline & \multirow[t]{2}{*}{ PCA } & 33 & 0.12 & 0.51 & 0.03 \\
\hline & & $0-99$ & $0-79$ & $0-100$ & $0-22$ \\
\hline & \multirow[t]{2}{*}{ GA-DFA 1} & 56 & 0.08 & 0.31 & 0.04 \\
\hline & & $0-100$ & $0-67$ & $0-100$ & $0-34$ \\
\hline & \multirow[t]{2}{*}{ GA-DFA 2} & 50 & 0.09 & 0.36 & 0.04 \\
\hline & & $0-100$ & $0-71$ & $0-100$ & $0-36$ \\
\hline & \multirow[t]{2}{*}{ GA-DFA 3} & 53 & 0.09 & 0.34 & 0.04 \\
\hline & & $0-100$ & $0-64$ & $0-100$ & $0-36$ \\
\hline & Weighted average $^{a}$ & 45 & 10 & 41 & 4 \\
\hline \multirow{12}{*}{$\begin{array}{l}\text { May } 2011 \\
\quad \text { (Late spawning stage) }\end{array}$} & \multirow[t]{2}{*}{$\mathrm{KW}-\mathrm{H}$} & 41 & 13 & 42 & 4 \\
\hline & & $0-100$ & $0-76$ & $0-100$ & $0-30$ \\
\hline & \multirow[t]{2}{*}{ PCA } & 42 & 11 & 43 & 4 \\
\hline & & $0-100$ & $0-70$ & $0-100$ & $0-25$ \\
\hline & \multirow[t]{2}{*}{ GA-DFA 1} & 52 & 9 & 34 & 5 \\
\hline & & $0-100$ & $0-80$ & $0-100$ & $0-33$ \\
\hline & \multirow[t]{2}{*}{ GA-DFA 2} & 50 & 10 & 35 & 5 \\
\hline & & $0-100$ & $0-72$ & $0-100$ & $0-38$ \\
\hline & GA-DFA 3 & 53 & 9 & 33 & 5 \\
\hline & & $0-100$ & $0-69$ & $0-100$ & $0-34$ \\
\hline & Weighted average $\mathrm{e}^{\mathrm{a}}$ & 48 & 10 & 37 & 5 \\
\hline & Overall average $^{\mathrm{b}}$ & 44 & 11 & 41 & 4 \\
\hline
\end{tabular}

\footnotetext{
a Estimated using a weighting combining the GOF and \% discriminatory power for each signature.
}

b The overall average of the weighted average estimates for each basket extraction. 
contributions ranging between $18 \%$ (full uncertainty range $0-51 \%$ ) and $24 \%$ (full uncertainty range $0-72 \%$ ) at hatch and 53\% (full uncertainty range $0-96 \%$ ) and $42 \%$ (full uncertainty range $0-99 \%$ ) at late spawning stage. During the interstitial sediment sampling programme in each study area, the final weighted median relative contributions from farm manures/slurries were lowest at the River Rede site (26\%; full uncertainty range 0-77\%) and highest at the River Ithon study site (44\%; full uncertainty range 0-100\%). Table 1 shows that the organic carbon loading spread to agricultural land from farm manures $\left(140 \mathrm{t} \mathrm{km}^{-2} \mathrm{yr}^{-1}\right)$ in the River Rede catchment is considerably lower than the corresponding estimates for the River Ithon ( $565 \mathrm{t} \mathrm{km}^{-2} \mathrm{yr}^{-1}$ ) and Lugg $\left(637 \mathrm{t} \mathrm{km}^{-2} \mathrm{yr}^{-1}\right)$ study areas, reflecting the differences in the stocking densities of cattle, sheep, pigs and poultry. The averaged median contribution from farm yard manures/slurries across the sampling sites on the Rivers
Ithon, Lugg and Rede was 33\% (full uncertainty range 0-86\%). Most farm manures/slurries have a high biochemical oxygen demand (BOD) of $10,000-30,000 \mathrm{mg} \mathrm{L}^{-1}$ (MAFF, 1998) and can therefore contribute strongly to the degradation of dissolved oxygen supply in the fish egg incubation zone. Salmonid embryos can tolerate low dissolved oxygen supply for short periods especially at the start of the incubation period on account of their low respiratory rates (Hamor and Garside, 1976; Malcolm et al., 2008), but the source fingerprinting estimates in Tables 9-11 revealed significant contributions from this potentially damaging source at all of the embryonic stages of fish development and especially at late spawning in May, 2011. For example, at the River Lugg sampling site, the final estimated median contribution from farm manures/ slurries at late spawning was 53\% (full uncertainty range 0-96\%) compared with $26 \%$ (full uncertainty range 0-99\%) at the eyeing

Table 10

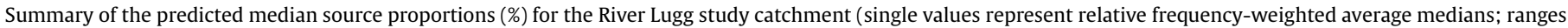
represent the full uncertainty in the median contributions predicted by the Monte Carlo repeat runs of the mass balance model).

\begin{tabular}{|c|c|c|c|c|c|}
\hline Basket extraction & Signature & $\begin{array}{l}\text { Farm } \\
\text { yard } \\
\text { manure/ } \\
\text { slurries }\end{array}$ & $\begin{array}{l}\text { Damaged } \\
\text { road } \\
\text { verges }\end{array}$ & $\begin{array}{l}\text { Instream } \\
\text { decaying } \\
\text { vegetation }\end{array}$ & Human septic waste \\
\hline \multirow{11}{*}{$\begin{array}{l}\text { February } 2011 \\
\quad \text { (Eyeing stage) }\end{array}$} & \multirow[t]{2}{*}{$\mathrm{KW}-\mathrm{H}$} & 27 & 20 & 50 & 3 \\
\hline & & $0-96$ & $0-99$ & $0-100$ & $0-29$ \\
\hline & \multirow[t]{2}{*}{ PCA } & 26 & 21 & 49 & 3 \\
\hline & & $0-91$ & $0-100$ & $0-100$ & $0-41$ \\
\hline & \multirow[t]{2}{*}{ GA-DFA 1} & 24 & 12 & 60 & 3 \\
\hline & & $0-87$ & $0-100$ & $0-100$ & $0-35$ \\
\hline & \multirow{2}{*}{ GA-DFA 2} & 26 & 20 & 51 & 3 \\
\hline & & $0-91$ & 0-99 & $0-100$ & $0-36$ \\
\hline & \multirow[t]{2}{*}{ GA-DFA 3} & 24 & 13 & 59 & 3 \\
\hline & & $0-84$ & $0-99$ & $0-100$ & $0-28$ \\
\hline & Weighted average ${ }^{a}$ & 26 & 17 & 54 & 3 \\
\hline \multirow{11}{*}{$\begin{array}{l}\text { March } 2011 \\
\text { (Hatch stage) }\end{array}$} & \multirow[t]{2}{*}{$\mathrm{KW}-\mathrm{H}$} & 18 & 15 & 64 & 3 \\
\hline & & $0-52$ & $0-84$ & $0-100$ & $0-27$ \\
\hline & \multirow[t]{2}{*}{ PCA } & 18 & 16 & 63 & 3 \\
\hline & & $0-51$ & $0-82$ & $0-100$ & $0-29$ \\
\hline & \multirow[t]{2}{*}{ GA-DFA 1} & 17 & 9 & 72 & 3 \\
\hline & & $0-51$ & $0-76$ & $0-100$ & $0-25$ \\
\hline & \multirow[t]{2}{*}{ GA-DFA 2} & 18 & 15 & 64 & 3 \\
\hline & & $0-49$ & $0-80$ & $0-100$ & $0-27$ \\
\hline & \multirow[t]{2}{*}{ GA-DFA 3} & 17 & 10 & 71 & 3 \\
\hline & & $0-51$ & $0-82$ & $0-100$ & $0-24$ \\
\hline & Weighted average $^{a}$ & 18 & 13 & 66 & 3 \\
\hline \multirow{11}{*}{$\begin{array}{l}\text { April } 2011 \\
\quad \text { (Emergence stage) }\end{array}$} & \multirow[t]{2}{*}{ KW-H } & 22 & 21 & 54 & 3 \\
\hline & & $0-51$ & $0-84$ & $0-100$ & $0-29$ \\
\hline & \multirow[t]{2}{*}{ PCA } & 22 & 23 & 52 & 3 \\
\hline & & $0-52$ & $0-89$ & $0-100$ & $0-28$ \\
\hline & \multirow[t]{2}{*}{ GA-DFA 1} & 18 & 11 & 68 & 3 \\
\hline & & $0-52$ & $0-76$ & $0-100$ & $0-24$ \\
\hline & \multirow[t]{2}{*}{ GA-DFA 2} & 22 & 21 & 54 & 3 \\
\hline & & $0-53$ & $0-85$ & $0-100$ & $0-27$ \\
\hline & \multirow[t]{2}{*}{ GA-DFA 3} & 18 & 12 & 67 & 3 \\
\hline & & $0-51$ & $0-78$ & $0-100$ & $0-27$ \\
\hline & Weighted average $^{a}$ & 20 & 18 & 59 & 3 \\
\hline \multirow{12}{*}{$\begin{array}{l}\text { May } 2011 \\
\quad \text { (Late spawning stage) }\end{array}$} & \multirow[t]{2}{*}{$\mathrm{KW}-\mathrm{H}$} & 54 & 11 & 30 & 5 \\
\hline & & $0-97$ & $0-59$ & $0-99$ & $0-39$ \\
\hline & \multirow[t]{2}{*}{ PCA } & 53 & 13 & 29 & 5 \\
\hline & & $0-97$ & $0-61$ & $0-100$ & $0-44$ \\
\hline & \multirow[t]{2}{*}{ GA-DFA 1} & 53 & 7 & 36 & 4 \\
\hline & & $0-95$ & $0-56$ & $0-98$ & $0-34$ \\
\hline & \multirow[t]{2}{*}{ GA-DFA 2} & 54 & 12 & 30 & 5 \\
\hline & & 0-99 & $0-58$ & 0-99 & $0-45$ \\
\hline & GA-DFA 3 & 53 & 8 & 34 & 5 \\
\hline & & $0-91$ & $0-59$ & $0-94$ & $0-39$ \\
\hline & Weighted average $\mathrm{a}^{\mathrm{a}}$ & 53 & 10 & 32 & 5 \\
\hline & Overall average $^{\mathrm{b}}$ & 29 & 15 & 52 & 4 \\
\hline
\end{tabular}

\footnotetext{
a Estimated using a weighting combining the GOF and \% discriminatory power for each signature.
}

b The overall average of the weighted average estimates for each basket extraction. 
stage (Table 10). Similarly, at the River Rede sampling site, the final estimated median contribution from farm manures/slurries at late spawning was $42 \%$ (full uncertainty range 0-99\%) compared with $21 \%$ (full uncertainty range $0-75 \%$ ) at the eyeing stage (Table 11 ).

Median relative contributions from damaged road verges at the River Ithon sampling site (Table 9) were highest at eyeing and hatch stage (both $12 \%$; full uncertainty ranges $0-75 \%$ and $0-80 \%$, respectively). In contrast, damaged road verge contributions were highest at emergence stage at the sampling sites on both the River Lugg (18\%; full uncertainty range $0-81 \%$; Table 10 ) and River Rede (20\%; full uncertainty range $0-100 \%$; Table 11 ). The final weighted median relative contributions from damaged road verges over the duration of the interstitial sediment sampling ranged between $11 \%$ (full uncertainty range 0-75\%) at the sampling site on the River
Ithon and $16 \%$ (full uncertainty range $0-99 \%$ ) at the sampling site on the River Rede study area (see Tables 9 and 11, respectively). This source end member contributed an overall average median of $14 \%$ (full uncertainty range $0-78 \%$ ) of the interstitial sedimentassociated organic matter sampled in the Rivers Ithon, Lugg and Rede. Collins et al. (2013) reported a corresponding input of 39\% (full uncertainty range 0-77\%) working in the River Blackwater catchment, in southern England. Particulate material mobilised in association with the erosion and degradation of road verges by vehicle traffic and livestock movements frequently has a high likelihood of reaching river channels on account of the connectivity provided by road culverts or drains and river crossings.

Instream decaying vegetation was the most important source of interstitial sediment-associated organic matter at the River Lugg (52\%; full uncertainty range $0-100 \%$ ) and River Rede (48\%; full

Table 11

Summary of the predicted median source proportions (\%) for the River Rede study catchment (single values represent relative frequency-weighted average medians; ranges represent the full uncertainty in the median contributions predicted by the Monte Carlo repeat runs of the mass balance model).

\begin{tabular}{|c|c|c|c|c|c|}
\hline Basket extraction & Signature & $\begin{array}{l}\text { Farm } \\
\text { yard } \\
\text { manure/ } \\
\text { slurries }\end{array}$ & $\begin{array}{l}\text { Damaged } \\
\text { road } \\
\text { verges }\end{array}$ & $\begin{array}{l}\text { Instream } \\
\text { decaying } \\
\text { vegetation }\end{array}$ & Human septic waste \\
\hline \multirow{11}{*}{$\begin{array}{l}\text { February } 2011 \\
\text { (Eyeing stage) }\end{array}$} & \multirow[t]{2}{*}{$\mathrm{KW}-\mathrm{H}$} & 24 & 57 & 14 & 5 \\
\hline & & $0-80$ & $0-100$ & $0-71$ & $0-37$ \\
\hline & \multirow[t]{2}{*}{ PCA } & 19 & 53 & 21 & 7 \\
\hline & & $0-79$ & $0-100$ & $0-85$ & $0-39$ \\
\hline & \multirow[t]{2}{*}{ GA-DFA 1} & 20 & 55 & 20 & 5 \\
\hline & & $0-75$ & $0-100$ & $0-86$ & $0-37$ \\
\hline & \multirow[t]{2}{*}{ GA-DFA 2} & 24 & 55 & 20 & 5 \\
\hline & & $0-73$ & $0-100$ & $0-80$ & $0-36$ \\
\hline & \multirow[t]{2}{*}{ GA-DFA 3} & 21 & 57 & 16 & 6 \\
\hline & & $0-70$ & $0-100$ & $0-76$ & $0-39$ \\
\hline & Weighted average $^{a}$ & 21 & 55 & 18 & 6 \\
\hline \multirow{11}{*}{$\begin{array}{l}\text { March } 2011 \\
\quad \text { (Hatch stage) }\end{array}$} & \multirow[t]{2}{*}{ KW-H } & 27 & 56 & 11 & 5 \\
\hline & & $0-77$ & $0-100$ & $0-70$ & $0-34$ \\
\hline & \multirow{2}{*}{ PCA } & 22 & 53 & 18 & 7 \\
\hline & & $0-66$ & $0-100$ & $0-83$ & $0-41$ \\
\hline & \multirow[t]{2}{*}{ GA-DFA 1} & 23 & 54 & 16 & 7 \\
\hline & & $0-70$ & $0-100$ & $0-77$ & $0-42$ \\
\hline & \multirow[t]{2}{*}{ GA-DFA 2} & 24 & 56 & 14 & 7 \\
\hline & & $0-73$ & $0-100$ & $0-71$ & $0-43$ \\
\hline & \multirow[t]{2}{*}{ GA-DFA 3} & 24 & 56 & 13 & 7 \\
\hline & & $0-74$ & $0-100$ & $0-75$ & $0-39$ \\
\hline & Weighted average ${ }^{a}$ & 24 & 55 & 14 & 7 \\
\hline \multirow{11}{*}{$\begin{array}{l}\text { April } 2011 \\
\quad \text { (Emergence stage) }\end{array}$} & \multirow[t]{2}{*}{$\mathrm{KW}-\mathrm{H}$} & 20 & 58 & 16 & 6 \\
\hline & & $0-70$ & $0-100$ & $0-84$ & $0-38$ \\
\hline & \multirow[t]{2}{*}{ PCA } & 16 & 53 & 24 & 7 \\
\hline & & $0-57$ & $0-100$ & $0-91$ & $0-38$ \\
\hline & \multirow[t]{2}{*}{ GA-DFA 1} & 16 & 55 & 23 & 7 \\
\hline & & $0-62$ & $0-100$ & $0-100$ & $0-39$ \\
\hline & \multirow[t]{2}{*}{ GA-DFA 2} & 16 & 56 & 21 & 7 \\
\hline & & $0-58$ & $0-100$ & $0-86$ & $0-36$ \\
\hline & \multirow[t]{2}{*}{ GA-DFA 3} & 17 & 57 & 19 & 7 \\
\hline & & $0-60$ & $0-100$ & $0-82$ & $0-37$ \\
\hline & Weighted average $^{a}$ & 17 & 56 & 20 & 7 \\
\hline \multirow{12}{*}{$\begin{array}{l}\text { May } 2011 \\
\quad \text { (Late spawning stage) }\end{array}$} & \multirow[t]{2}{*}{$\mathrm{KW}-\mathrm{H}$} & 48 & 25 & 11 & 15 \\
\hline & & $0-100$ & $0-97$ & $0-63$ & $0-58$ \\
\hline & \multirow[t]{2}{*}{ PCA } & 39 & 27 & 14 & 19 \\
\hline & & $0-98$ & $0-93$ & $0-73$ & $0-66$ \\
\hline & \multirow[t]{2}{*}{ GA-DFA 1} & 39 & 28 & 13 & 20 \\
\hline & & $0-100$ & $0-94$ & $0-70$ & $0-65$ \\
\hline & \multirow[t]{2}{*}{ GA-DFA 2} & 40 & 28 & 12 & 19 \\
\hline & & $0-99$ & $0-97$ & $0-64$ & $0-59$ \\
\hline & GA-DFA 3 & 42 & 28 & 12 & 18 \\
\hline & & $0-100$ & $0-95$ & $0-67$ & $0-61$ \\
\hline & Weighted average ${ }^{a}$ & 42 & 27 & 13 & 18 \\
\hline & Overall average $^{\mathrm{b}}$ & 26 & 48 & 16 & 10 \\
\hline
\end{tabular}

\footnotetext{
a Estimated using a weighting combining the GOF and \% discriminatory power for each signature.
}

b The overall average of the weighted average estimates for each basket extraction. 
uncertainty range $0-78 \%$ ) sampling sites and the second most important after farm manures/slurries at the River Ithon (41\%; full uncertainty range $0-100 \%$ ) sampling site. The overall average median contribution from this catchment source to the interstitial sediment-associated organic matter across the three channel sampling sites was $47 \%$ (full uncertainty range 0-100\%). Increased shear stress in conjunction with higher flows can mobilise inchannel decaying vegetation and evidence has demonstrated that some of this material can infiltrate spawning gravels thereby contributing to oxygen consumption via subsequent decomposition (Whitmore and Clark, 1982; Soulsby et al., 2001, 2009). Since much of the instream decaying vegetation will originate from riparian trees and bushes as well emergent and submergent macrophytes, the importance of this source type underscores the linkages between well-connected riparian areas and aquatic ecology in the context of the supply of leaf litter (cf. Meador and Goldstein, 2003; Feld, 2013).

Human septic waste consistently contributed the smallest proportion (6\%; full uncertainty range $0-31 \%$ ) of the interstitial sediment-associated organic matter sampled from the study sites. The final weighted median contributions were highest (10\%; full uncertainty range $0-44 \%$ ) at the River Rede sampling site (Table 11), despite this study catchment having the lowest estimated density ( 0.2 properties $/ \mathrm{km}^{2}$ ) of unconnected domestic properties (Table 1). The highest median contribution from human septic waste during the sampling period was $18 \%$ (full uncertainty range $0-62 \%$ ) at the late spawning stage on the River Rede in May 2011 (Table 11). Septic tank discharges pose a risk to water quality in many rural areas in the UK (May et al., 2011) and reasons for failure include irregular cleaning out, poor maintenance and the fact that many tanks are inefficient since they have been in situ for >25 years (cf. Day, 2004; Beal et al., 2005; May et al., 2011). In addition, hydraulic failure can result from the soil surface in septic tank drainage fields being clogged by biomats (Ahmed et al., 2005).

Algal biofilms embedded within secretions of extra-cellular polymeric substances (EPS) can inhabit the benthic environment of rivers (Sierra and Gomez, 2007). Biofilm development can be enhanced in situations where high loadings of organic material are present in the interstitial environment, although nutrient supply, light and temperature are also important controls on algae blooms. Algae were not included as a potential source of sedimentassociated organic matter in this study since the sampling strategy coincided with the winter and spring rainfall periods during which algae were observed to be scarce in the study systems (cf. McConnachie and Petticrew, 2006) and during which any signal from algae could be assumed to be overrun by the more significant inputs of organic material from decaying instream vegetation and other sources. Lower river water temperatures during the winter season contribute to the reduced presence of algae in the study rivers at the time of sampling. If the sampling strategy had coincided with, or included the summer season, when algae signals could be expected to be more important in a year with typical weather patterns, due to reduced inputs from allochthonous sources which are more rainfall and runoff dependent, or from instream vegetation on account of growth rather than die back, it would have been more appropriate to have included algae as a potential source of sediment-associated organic matter. Furthermore, in the context of catchment management, it is meaningful to remember that significant algae blooms are, in part, the product of inputs of organic material from other sources such as those sampled in this study and indeed excessive nutrient supply (e.g. Jarvie et al., 2005). Effective catchment management strategies need to focus on the key primary sources of pollution to deliver sustainable solutions and as such, the control of algae blooms is dependent upon controls targeting other sources.
Whilst it has proved possible to differentiate algae from other sources using carbon and nitrogen stable isotope data (e.g. McConnachie and Petticrew, 2006), it is important to satisfy dimensionality by ensuring that the number of properties comprising composite signatures exceeds the number of end members. The sourcing procedure based on stable isotope and NIR data described in this contribution needs to be tested with regards its utility for distinguishing algae from the other catchment sources of sediment-associated organic matter. Readers are reminded that the source proportions reflect the contributions from the end members included in the sampling strategy and that inclusion of additional sources will inevitably influence the ascription provided by the mixing model.

The mass conservation test in Table 2 clearly illustrates the importance of testing for significant tracer transformation which is an essential requirement when using the fingerprinting approach. In the case of the bulk stable isotope data, non-conservative behaviour is possible on account of fractionation during carbon and nitrogen transformations in the aquatic environment. Bulk stable ${ }^{13} \mathrm{C}$ values did not pass the range test for any of the sampling sites except the one on the River Lugg (Table 2). Decomposition can alter the bulk $\delta^{13} \mathrm{C}$ values of organic matter (Benner et al., 1987) and mineralisation is generally believed to generate some carbon isotopic fractionation (Fogel and Cifuentes, 1993). Biogenic methanogenesis might also be a factor at play and this is characterised by depleted $\delta^{13} \mathrm{C}$ values (Conrad, 2005). Considerable spatio-temporal variation in $\delta^{13} \mathrm{C}$ values has been reported in conjunction with instream production (Finlay et al., 1999). In contrast, the bulk nitrogen isotope values passed the mass conservation test for all of the sampling sites (Table 2). It is, nevertheless, important to recognise that nitrogen isotopic fractionation can be induced by a number of processes including nitrification, denitrification, nitrogen fixation and assimilation (Montoya and McCarthy, 1995; Lehmann et al., 2002; Hantush, 2007; Herman et al., 2008). On this basis, the tendency for transformations of bulk isotope fingerprints during fluvial transport warrants further work (Kendall et al., 2001; Fox et al., 2010). Although the mass conservation tests for this study clearly show that the bulk isotopic properties are not suitable for source fingerprinting at some sites, it must be acknowledged that it is possible that they might work at different sampling sites within the same study rivers. The NIR spectra in Fig. 2 revealed either complete (sampling sites on the Rivers Aran and Test) or partial (sampling sites on the Rivers Ithon, Lugg and Rede) nonconservatism on the basis of a comparison between the source end member and interstitial sediment samples. Previous work by Poulenard et al. $(2009,2012)$ using specific peaks within, as opposed to entire, NIR spectra, has reported conservative behaviour in the fluvial environment on the basis of in-river experimental work.

Further work is required to provide guidance on the selection of channel sampling sites for the successful application of source tracing using bulk stable isotope analyses of carbon and nitrogen and NIR spectra with and without further correction factors for both selectivity and transformation and to assess the sensitivity of predicted source proportions to such alteration, even in the context of a dataset which passes the mass conservation test. Because the mass balance model reported by Collins et al. (2013) and used by this study includes functionality for the selection from pdfs of a range of deviate median tracer values for the interstitial sediment samples, as opposed to a single value (e.g. the value for an individual sample or the median of several samples), some of the potential impact of tracer transformation will be taken into account. The range test is, nevertheless, an oversimplistic or black box approach on the basis of a direct comparison between source end member samples and in-river 
sediment, without any intervening sampling and consideration of the evolution of the fingerprints in conjunction with the delivery of particulate matter through different components of the catchment system each with their various environmental controls (Koiter et al., 2013). In the case of bulk stable isotope values, simple corrections for tracer transformation could be based on the ratio of the isotopic values of the interstitial sediment to those of each source end member. Simple correction factors for selectivity could also be devised in the same manner but using the TOC and TN data provided as part of isotopic assessments, although Collins et al. (2013) reported that this approach resulted in over-correction problems. Such simplistic and aggregated correction factors would not, however, provide a means of resolving detail in terms of the key controls on tracer values measured in the fluvial environment. A well designed study is required to assess correlations between conservative and non-conservative tracer behaviour and the environmental controls persisting at different sites within river catchments. In the absence of such detail and to provide direct comparison with the previous investigation of Collins et al. (2013); this study applied the bulk stable carbon and nitrogen isotope values and NIR spectra without any simplistic corrections for selectivity or transformation.

\section{Conclusions}

This paper has reported the application of a composite fingerprinting procedure for fluvial sediment-associated organic matter recovered from artificial redds constructed in salmonid spawning gravels. Mass conservation tests demonstrated that the procedure, without corrections for tracer selectivity or transformation, is not guaranteed to work at all river channel sampling sites. The final estimated source proportions were based on a weighting combining the GOF and discriminatory power of different composite signatures. Bearing in mind the scale dependency of the source proportions given that the artificial redds were inserted at a single sampling site on each study river as opposed to multiple sites (cf. Collins et al., 2012a), the final estimated median relative contributions from the source end members were in the order: instream decaying vegetation $>$ farm manures/slurries $>$ damaged road verges $>$ human septic waste. The full uncertainty ranges for the predicted median source proportions represent feasible solutions and in this study these ranges are appreciable. Against this background, the calculation of relative frequency-weighted average median source proportions (e.g. Collins et al., 2012b, 2013) based on the uncertainty outputs generated by the mass balance modelling delivers more readily interpretable information for catchment management. Critically, these estimates take explicit account of all of the feasible model solutions but summarise these as single values weighted towards central tendency which are easier for stakeholders to interpret. In the absence of such weighted estimates, interpretation of the full uncertainty ranges where these are substantial and heavily overlapping would be more challenging in terms of devising targeted catchment management strategies. Since the full uncertainty ranges in predicted source proportions are based, in part, on the corresponding variation in source fingerprints, the latter should be considered carefully in the selection of tracer properties, in addition to mass conservation alone. Given the high BOD of farm manures/slurries, these findings illustrate the importance of controlling better their loss to watercourses. The results also suggest, in accordance with the findings for the River Blackwater, in southern England, previously reported by Collins et al. (2013); that human septic waste does contribute to organic matter loadings in the salmonid spawning environment in the study areas used for this subsequent investigation.

\section{Acknowledgements}

The funding provided by the Department for Environment, Food and Rural Affairs (Defra) under project WQ0128 (extending the evidence base on the ecological impacts of fine sediment and developing a framework for targeting mitigation of agricultural sediment losses) is gratefully acknowledged. Access to source and sediment sampling sites was provided by landowners. Stephen Haley assisted with the field sampling whilst working at ADAS. Roland Bol arranged bulk stable isotope analysis at Rothamsted Research-North Wyke. Professor Malcolm Newson provided support and advice for the work on the River Rede catchment.

\section{References}

Acornley, R.M., Sear, D.A., 1999. Sediment transport and siltation of brown trout (Salmo trutta L.) spawning gravels in chalk streams. Hydrol. Process. 13, 447458.

Ahmed, W., Neller, R., Katouli, M., 2005. Evidence of septic system failure determined by a bacterial fingerprinting method. J. Appl. Microbiol. 98, 910-920.

Armstrong, J.D., Kemp, P.S., Kennedy, G.J.A., Ladle, M., Milner, N.J., 2003. Habitat requirements of Atlantic salmon and brown trout in rivers and streams. Fish. Res. 62, 143-170.

Beal, C.D., Gardner, E.A., Menzies, N.W., 2005. Process, performance, and pollution potential: a review of septic tank-soil absorption systems. Aust. J. Soil Res. 43, 781-802.

Benner, R., Fogel, M.L., Sprague, E.K., Hodson, R.E., 1987. Depletion of ${ }^{13} \mathrm{C}$ in lignin and its implications for stable isotope studies. Nature 329, 708-710.

Blanco, M., Villarroya, I., 2002. NIR spectroscopy: a rapid-response analytical tool. Trends Anal. Chem. 21, 240-250.

Boulton, A.J., Findlay, S., Marmonier, P., Stanley, E.H., Valett, H.M., 1998. The functional significance of the hyporheic zone in streams and rivers. Annu. Rev. Ecol. Syst. 29, 59-81.

Chevalier, B.C., Carson, C., Miller, W.J., 1984. Report of engineering and biological literature pertaining to the aquatic environment: with special emphasis on dissolved oxygen and sediment effects on salmonid habitat, Colorado State University, Dept. Agr. and Chem. Eng. ARS. Project No 5602-20813-008A.

Collins, A.L., McGonigle, D.F., Evans, R., Zhang, Y., Duethmann, D., Gooday, R., 2009 Emerging priorities in the management of diffuse pollution at catchment scale. Int. J. River Basin Manag. 7,179-185.

Collins, A.L., Walling, D.E., McMellin, G.K., Zhang, Y., Gray, J., McGonigle, D., Cherrington, R., 2010a. A preliminary investigation of the efficacy of riparian fencing schemes for reducing contributions from eroding channel banks to the siltation of salmonid spawning gravels across the south west UK. J. Environ. Manage. 91, 1341-1349.

Collins, A.L., Walling, D.E., Webb, L., King, P., 2010c. Apportioning catchment scale sediment sources using a modified composite fingerprinting technique incorporating property weightings and prior information. Geoderma 155, 249-261.

Collins, A.L., Zhang, Y., Walling, D.E., Grenfell, S.E., Smith, P., 2010b. Tracing sediment loss from eroding farm tracks using a geochemical fingerprinting procedure combining local and genetic algorithm optimisation. Sci. Total Environ. 408, $5461-5471$.

Collins, A.L., Zhang, Y., Walling, D.E., Grenfell, S.E., Smith, P., Grischeff, J., A, Locke, Sweetapple, A., Brogden, D., 2012a. Quantifying fine-grained sediment sources in the River Axe catchment, southwest England: application of a Monte Carlo numerical modelling framework incorporating local and genetic algorithm optimisation. Hydrol. Process. 26, 1962-1983.

Collins, A.L., Zhang, Y., McChesney, D., Walling, D.E., Haley, S.M., Smith, P., 2012b. Sediment source tracing in a lowland agricultural catchment in southern England using a modified procedure combining statistical analysis and numerical modelling. Sci. Total Environ. 414, 301-317.

Collins, A.L., Williams, L.J., Zhang, Y.S., Marius, M., Dungait, J.A.J., Smallman, D.J., Dixon, E.R., Stringfellow, A., Sear, D.A., Jones, J.I., Naden, P.S., 2013. Catchment source contributions to the sediment-bound organic matter degrading salmonid spawning gravels in a lowland river, southern England. Sci. Total Environ. 456457, 181-195.

Comber, A., Anthony, A., Proctor, C., 2008. The creation of a national agricultural land use dataset: combining pycnophylactic interpolation with dasymetric mapping techniques. Trans. GIS 12, 775-791.

Conrad, R., 2005. Quantification of methanogenic pathways using stable carbon isotopic signatures: a review and a proposal. Org. Geochem. 36, 739-752.

Crisp, D.T., Carling, P.A., 1989. Observations on siting, dimensions and structure of salmonid redds. J. Fish Bio. 34, 119-134.

Day, L., 2004. Septic systems as potential pollution sources in the Cannonsville Reservoir watershed, New York. J. Environ. Qual. 33, 1989-1996.

Duff, J.H., Triska, F.J., 2000. Nitrogen biogeochemistry and surface-subsurface exchange in streams. In: Jones, J.B., Mulholland, P.J. (Eds.), Streams and Ground Waters. Academic Press, California.

Dungait, J.A., Bol, R., Evershed, R.P., 2005. Quantification of dung carbon incorporation in a temporate grassland soil following spring application using 
bulk stable carbon isotope determinations. Isotopes Environ. Health Stud. 41, 311.

Dungait, J.A.J., Bol, R., Lopez-Capel, E., Bull, I.D., Chadwick, D., Amelung, W., Granger, S.J., Manning, D.A.C., Evershed, R.P., 2010. Applications of stable isotope ratio mass spectrometry in cattle dung carbon cycling studies. Rapid Commun. Mass Spectrom. 24, 495-500.

Elliott, G.N., Worgan, H., Broadhurst, D., Draper, J., Scullion, J., 2007. Soil differentiation using fingerprint Fourier transform infrared spectroscopy, chemometrics and genetic algorithm-based feature selection. Soil. Biol. Biochem. 39, 2888-2896.

Esteve Agelet, L., Hurburgh, C.R., 2010. A tutorial on near infrared spectroscopy and its calibration. Crit. Rev. Anal. Chem. 40, 246-260.

Feld, C.K., 2013. Response of three lotic assemblages to riparian and catchmentscale land use: implications for designing catchment monitoring programmes. Freshwater Bio. 58, 715-729.

Finlay, J.C., Power, M.E., Cabana, G., 1999. Effects of water velocity on algal carbon isotope ratios: implications for river food web studies. Limnol. Oceanogr. 44, 1198-1203.

Finn, R.N., 2007. The physiology and toxicology of salmonid eggs and larvae in relation to water quality criteria. Aquat. Toxicol. 81, 337-354.

Fogel, M., Cifuentes, L., 1993. Isotope fractionation during primary production. In: Engel, M.H., Macko, S.A. (Eds.), Organic Geochemistry: Principles Applications. Plenum Press, New York, pp. 73-98.

Foley, W.J., McIlwee, A., Lawler, I., Aragones, L., Woolnough, A.P., Berding, N., 1998. Ecological applications of near infrared reflectance spectroscopy - a tool for rapid, cost-effective prediction of the composition of plant and animal tissues and aspects of animal performance. Oecologia 116, 293-305.

Fox, J.F., 2009. Measurements of sediment transport processes in forested watersheds with surface coal mining disturbance using carbon and nitrogen isotopes. J. Am. Water Res. Ass. 45, 1273-1289.

Fox, J.F., Papanicolaou, A.N., 2008. Model of the spatial distribution of nitrogen stable isotopes for sediment tracing at the watershed scale. J. Hydrol. 358, 4655.

Fox, J.F., Davis, C.M., Martin, D.K., 2010. Sediment source assessment in a lowland watershed using nitrogen stable isotopes. J. Am. Water Res. Ass. 46, 1192-1204.

Glaser, B., Bol, R., Preedy, N., Mctiernan, K., Clark, M., Amelung, W., 2001. Short-term sequestration of slurry-deriver carbon and nitrogen in temperate grassland soil as assessed by ${ }^{13} \mathrm{C}$ and ${ }^{15} \mathrm{~N}$ natural abundance measurements. J. Plant Nutrit. Soil Sci. 164, 467-474.

Greig, S.M., Sear, D.A., Carling, P.A., 2006. A review of factors influencing the availability of dissolved oxygen to incubating salmonid embryos. Hydrol. Process. 21 (3), 323-334.

Greig, S.M., Sear, D.A., Carling, P.A., 2007. Review of factors influencing the availability of dissolved oxygen to incubating salmon embryos. Hydrol. Process. 21, 323-324.

Guo, L., Macdonald, R.W., 2006. Source and transport of terrigenous organic matter in the upper Yukon River: evidence from isotope $\left(\bumpeq{ }^{13} \mathrm{C}, \bumpeq{ }^{14} \mathrm{C}\right.$, and $\left.\bumpeq{ }^{15} \mathrm{~N}\right)$ composition of dissolved, colloidal, and particulate phases. Global Biogeochem. Cy. 20, GB2011.

Hamor, T., Garside, E.T., 1976. Developmental rates of embryos of Atlantic salmon, Salmo salar L., in response to various levels of temperature, dissolved oxygen, and water exchange. Can. J. Zool. 54, 1912-1917.

Hantush, M.M., 2007. Modelling nitrogen-carbon cycling and oxygen consumption in bottom sediments. Adv. Water Resour. 30, 59-79.

Hillier, S., 2001. Particulate composition and origin of suspended sediment in the R. Don Aberdeenshire, U.K. Sci. Total Environ. 265, 281-293.

Herman, K., Bouchard, V., Moore, R., 2008. Factors affecting denitrification in agricultural headwater streams in Northeast Ohio, USA. Hydrobiologia 598, 305-314.

House, W.A., 2003. Factors influencing the extent and development of the oxic zone in sediments. Biogeochemistry 63 (3), 317-333.

Jacinthe, P., Lal, R., Owens, L., 2009. Application of stable isotope analysis to quantify the retention of eroded carbon grass filters at the North Appalachian experimental watersheds. Geoderma 148, 405-412.

Jankowski, K., Schindler, D.E., Holtgrieve, G.W., 2012. Assessing nonpoint-source nitrogen loading and nitrogen fixation in lakes using $\delta^{15} \mathrm{~N}$ and nutrient stoichiometry. Limnol. Oceanogr. 57, 671-683.

Jarvie, H.P., Neal, C., Withers, P.J.A., Westcott, C., Acornley, R.M., 2005. Nutrient hydrochemistry for a groundwater-dominated catchment: the Hampshire Avon, UK. Sci. Total Environ. 344, 143-158.

Kendall, C., Silva, S.R., Kelly, V.J., 2001. Carbon and nitrogen isotopic compositions of particulate organic matter in four large river systems across the United States. Hydrol. Process. 15, 1301-1346.

Koiter, A.J., Owens, P.N., Petticrew, E.L., Lobb, D.A., 2013. The behavioural characteristics of sediment properties and their implications for sediment fingerprinting as an approach for identifying sediment sources in river basins. Earth Sci. Rev. 125, 24-42.

Kriszan, M., Amelung, W., Schellberg, J., Gebbing, T., Kühbauch, W., 2009. Long-term changes of the $\delta^{15} \mathrm{~N}$ natural abundance of plants and soil in a temperate grassland. Plant Soil 325, 157-169.

Lehmann, M., Bernasconi, S., Barbieri, A., McKenzie, J., 2002. Preservation of organic matter and alteration of its carbon and nitrogen isotope composition during simulated and in situ early sedimentary diagenesis. Geochim. Cosmochim. Acta $66,3573-3584$.

Lisle, T.E., 1989. Sediment transport and resulting deposition in spawning gravels, north coastal California. Water Resour. Res. 25, 247-260.
Lynch, D.H., Voroney, R.P., Warman, P.R., 2006. Use of ${ }^{13} \mathrm{C}$ and ${ }^{15} \mathrm{~N}$ natural abundance techniques to characterize carbon and nitrogen dynamics in composting and in compost-amended soils. Soil Biol. Biochem. 38, 103-114.

MAFF, 1998. Code of Good Agricultural Practice for the Protection of Water.. Ministry of Agriculture Fisheries and Food Publications, Publication PB0585, London.

Malard, F., Hervant, F., 1999. Oxygen supply and the adaptations of animals in groundwater. Freshwater Bio. 41, 1-30.

Malcolm, I.A., Youngson, A., Soulsby, C., 2003. Survival of salmonid eggs in gravel bed streams: effects of groundwater - surface water interactions. River Res. Appl. 19, 303-316.

Malcolm, I.A., Greig, S.M., Youngson, A.F., Soulsby, C., 2008. Hyporheic influences on salmon embryo survival and performance. In: Sear, D.A., DeVries, P. (Eds.), Salmonid Spawning Habitat in Rivers; Physical Controls, Biological Responses and Approaches to Remediation. AFS, Bethesda, Maryland, USA, pp. 225-248.

Martínez-Carreras, N., Krein, A., Udelhoven, T., Gallart, F., Iffly, J.F., Hoffmann, L., Pfister, L., Walling, D.E., 2010. A rapid spectral-reflectance-based fingerprinting approach for documenting suspended sediment sources during storm runoff events. J. Soils Sediment 10, 400-413.

May, L., Place, C., O’Malley, M.O., Spears, B., 2011. The impact of phosphorus inputs from small discharges on designated freshwater sites. Final report to Natural England and the Broads Authority, $130 \mathrm{pp}$.

McConnachie, J.L., Petticrew, E.L., 2006. Tracing organic matter sources in riverine suspended sediment: implications for fine sediment transfers. Geomorphology 79, 13-26.

Meador, M.R., Goldstein, R.M., 2003. Assessing water quality at large geographic scales: relations among land use, water physicochemistry, riparian condition, and fish community structure. Environ. Manage. 31, 504-517.

Michener, R., Lajtha, K., 2007. Stable Isotopes in Ecology and Environmental Science, second ed. Blackwell Publishing, USA.

Montoya, J.P., McCarthy, J.J., 1995. Isotopic fractionation during nitrate uptake by phytoplankton grown in continuous culture. J. Plankton Res. 17, 439-464.

Mukundan, R., Radcliffe, D.E., Ritchie, J.C., Risse, J.C., McKinley, R.A., 2010. Sediment fingerprinting to determine the source of suspended sediment in a southern Piedmont stream. J. Environ. Qual. 39, 1-10.

Mukundan, R., Walling, D.E., Gellis, A.C., Slattery, M.C., Radcliffe, D.E., 2012. Sediment source fingerprinting: transforming from a research tool to a management tool. J. Am. Water Res. Ass. 48, 1241-1257.

Papanicolaou, A.N., Fox, J.F., Marshall, J., 2003. Soil fingerprinting in the Palouse Basin USA using stable carbon and nitrogen isotopes. Int. J. Sediment Res. 18, 291-297.

Pellicer, A., Bravo, M. del C., 2011. Near-infrared spectroscopy: a methodologyfocused review. Semin. Fetal Neonatal Med. 16, 42-49.

Peterson, N.P., Quinn, T.P., 1996. Spatial and temporal variation in dissolved oxygen in natural egg pockets of chum salmon in Kennedy Creek, Washington. J. Fish Biol. 48, 131-143.

Poulenard, J., Perrette, Y., Fanget, B., Quetin, P., Trevisan, D., Dorioz, J.M., 2009. Infrared spectroscopy tracing of sediment sources in a small rural watershed (French Alps). Sci. Total Environ. 407, 2808-2819.

Poulenard, J., Legout, C., Némery, J., Bramorski, J., Navratil, O., Douchin, A., Fanget, B. Perrette, Y., Evrard, O., Esteves, M., 2012. Tracing sediment sources during floods using diffuse reflectance infrared fourier transform spectrometry (DRIFTS): a case study in a highly erosive mountainous catchment (Southern French Alps). J. Hydrol. 414-415, 452-462.

Richardson, A.D., Reeves, J.B., Gregoire, T.G., 2003. Multivariate analyses of visible/ near infrared (VIS/NIR) absorbance spectra reveal underlying spectral differences among dried, ground conifer needle samples from different growth environments. New Phytol. 161, 291-301.

Rubin, J.F., Glimsater, C., 1996. Egg-to-fry survival of the sea trout in some streams of Gotland. J. Fish Biol. 48, 585-606.

Sader, J.A., Hattori, K., Hamilton, S., Brauneder, K., 2011. Metal binding to dissolved organic matter and adsorption to ferrihydrite in shallow peat groundwaters: application to diamond exploration in the James Bay Lowlands, Canada. App. Geochem. 26 (9-10), 1649-1664.

Sear, D.A., Pattison, I., Collins, A.L., Newson, M.D., Jones, J.I., Naden, P.S., Carling, P.A., 2013. Factors controlling the temporal variability in dissolved oxygen regime of salmon spawning gravels. Hydrol. Process. doi:http://dx.doi.org/10.1002/ hyp.9565A.L.

Shumway, D.L., Warren, C.E., Doudoroff, P., 1964. Influence of oxygen concentration and water movement on the growth of steelhead trout and coho salmon embryos. Trans. Am. Fish. Soc. 93, 342-356.

Sierra, M.V., Gomez, N., 2007. Structural characteristics and oxygen consumption of the epipelic biofilm in three lowland streams exposed to different land uses. Water Air Soil Pollut. 186, 115-127.

Soulsby, C., Malcolm, I.A., Youngson, A.F., 2001. The hydrochemistry of the hyporheic zone in salmon spawning gravels: a preliminary assessment in a small regulated stream. Regul. Rivers 17, 651-665.

Soulsby, C., Malcolm, I.A., Tetzlaff, D., Youngson, A.F., 2009. Seasonal and interannual variability in hyporheic water quality revealed by continuous monitoring in a salmon spawning stream. River Res. Appl. 10, 1304-1319.

Storey, R.G., Williams, D.D., Fulthorpe, R.R., 2004. Nitrogen processing in the hyporheic zone of a pastoral stream. Biogeochemistry 69 (3), 285-313.

Walling, D.E., Collins, A.L., 2000. Integrated Assessment of Catchment Sediment Budgets: A Technical Manual. University of Exeter, UK.

Walling, D.E., Collins, A.L., McMellin, G., 2003. A reconnaissance survey of the source of interstitial fine sediment recovered from salmonid spawning gravels in England and Wales. Hydrobiologia 497, 91-108. 
Wessels, C.B., Malan, F.S., Rypstra, T., 2011. A review of measurement methods used on standing trees for the prediction of some mechanical properties of timber. Eur. J. For. Res. 130, 881-893.

Whitmore, R.L., Clark, W.J., 1982. Availability of dissolved oxygen in interstitial waters of a sandy creek. Hydrobiologia 92, 651-658.

Xiao, H.-Y., Liu, C.-Q., 2010. Identifying organic matter provenance in sediments using isotopic ratios in an urban river. Geochem. J. 44, 181-187.
Youngson, A.F., Malcolm, I.A., Thorley, J.L., Bacon, P.J., Soulsby, C., 2004. Longresidence groundwater effects on incubating salmonid eggs: low hyporheic oxygen impairs embryo development and causes mortality. Can. J. Fish. Aquat. Sci. 61, 2278-2287.

Zimmerman, A.E., Lapointe, M., 2005. Intergranular flow velocity through salmonid redds: sensitivity to fines infiltration from low intensity sediment transport events. River Res. Appl. 21, 865-881. 